\title{
Globally significant greenhouse-gas emissions from African inland waters
}

\author{
Alberto V. Borges ${ }^{1 \star}$, François Darchambeau', Cristian R. Teodoru², Trent R. Marwick², \\ Fredrick Tamooh ${ }^{2,3}$, Naomi Geeraert ${ }^{2}$, Fredrick 0. Omengo $^{2}$, Frédéric Guérin ${ }^{4}$, Thibault Lambert ${ }^{1}$, \\ Cédric Morana ${ }^{2}$, Eric Okuku ${ }^{2,5}$ and Steven Bouillon ${ }^{2}$
}

\begin{abstract}
Carbon dioxide emissions to the atmosphere from inland waters-streams, rivers, lakes and reservoirs-are nearly equivalent to ocean and land sinks globally. Inland waters can be an important source of methane and nitrous oxide emissions as well, but emissions are poorly quantified, especially in Africa. Here we report dissolved carbon dioxide, methane and nitrous oxide concentrations from 12 rivers in sub-Saharan Africa, including seasonally resolved sampling at 39 sites, acquired between 2006 and 2014. Fluxes were calculated from published gas transfer velocities, and upscaled to the area of all sub-Saharan African rivers using available spatial data sets. Carbon dioxide-equivalent emissions from river channels alone were about 0.4 Pg carbon per year, equivalent to two-thirds of the overall net carbon land sink previously reported for Africa. Including emissions from wetlands of the Congo river increases the total carbon dioxide-equivalent greenhouse-gas emissions to about $0.9 \mathrm{Pg}$ carbon per year, equivalent to about one quarter of the global ocean and terrestrial combined carbon sink. Riverine carbon dioxide and methane emissions increase with wetland extent and upland biomass. We therefore suggest that future changes in wetland and upland cover could strongly affect greenhouse-gas emissions from African inland waters.
\end{abstract}

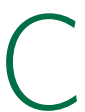
limate predictions necessitate a full and robust account of natural and anthropogenic greenhouse-gas (GHG) fluxes, especially for $\mathrm{CO}_{2}$ (refs 1-3), $\mathrm{CH}_{4}$ (ref. 4) and $\mathrm{N}_{2} \mathrm{O}$ (ref. 5), which together accounted for $94 \%$ of the anthropogenic global radiative forcing by well-mixed GHGs in 2011 relative to 1750 (ref. 6). Inland waters (streams, rivers, lakes and reservoirs) are increasingly recognized as important sources of GHGs to the atmosphere, with global $\mathrm{CO}_{2}$ and $\mathrm{CH}_{4}$ emissions estimated at $2.1 \mathrm{PgCyr}^{-1}$ (ref. 3) and $0.7 \mathrm{PgCyr}^{-1}\left(\mathrm{CO}_{2}\right.$-equivalents; $\left.\mathrm{CO}_{2} \mathrm{e}\right)$ (ref. 4) $\left(1 \mathrm{Pg}=10^{15} \mathrm{~g}\right)$, respectively. Considering that the oceanic and land carbon $(\mathrm{C})$ sinks correspond to $\sim 1.5$ and $\sim 2.0 \mathrm{PgC} \mathrm{yr}^{-1}$ (ref. 7), respectively, the GHG flux from inland waters is significant in the global $\mathrm{C}$ budget.

In a recent global compilation of inland $\mathrm{CO}_{2}$ data $^{3},<20$ data points (out of 6,708, that is, $<0.3 \%$ ) represented African inland waters (with the exception of South Africa, which has been densely sampled), even though they account for $\sim 12 \%$ of both global freshwater discharge ${ }^{8}$ and riverine surface area $^{3}$, and include some of the largest rivers and lakes in the world. Equally for the global $\mathrm{CH}_{4}$ database, there is a strong under-representation of tropical inland waters, whereby a recent synthesis ${ }^{4}$ resorted to extrapolating $\mathrm{CH}_{4}$ fluxes from temperate rivers.

The prevailing large uncertainty involved in GHG flux estimates for inland waters, essentially due to the paucity of available data, is coupled to a poor understanding of underlying processes, both of which preclude gauging of future fluxes in response to human pressures. In particular, there is a need to further understand the link between inland water GHG fluxes and catchment characteristics, in particular regarding their connectivity with upland terrestrial ${ }^{9,10}$ and wetland ${ }^{11-13} \mathrm{C}$ production and stocks. The $\mathrm{CO}_{2}$ emissions from inland waters have been traditionally interpreted as fuelled by organic $\mathrm{C}$ from upland terrestrial biomass ${ }^{1,14}$. In the Amazon basin, $\mathrm{CO}_{2}$ emissions from floodplain lakes ${ }^{11}$ and from river channels ${ }^{12,13}$ have been attributed to organic and inorganic $\mathrm{C}$ from wetlands (flooded forest and macrophytes). Finally, recently recognized biases in computed $\mathrm{CO}_{2}$ data traditionally used in inland water studies ${ }^{15,16}$ highlight the requirement for careful data-quality checking and future emphasis on high-quality direct $\mathrm{CO}_{2}$ measurements.

In this study, we report an extensive compilation of dissolved $\mathrm{CO}_{2}, \mathrm{CH}_{4}$ and $\mathrm{N}_{2} \mathrm{O}$ concentrations (Supplementary Table 1) gathered in 12 river basins in sub-Saharan Africa (SSA; Fig. 1 and Supplementary Fig. 1). The rivers range from $7.8 \times 10^{3}$ to $3.7 \times 10^{6} \mathrm{~km}^{2}$ in watershed area and from 1.9 to $1.3 \times 10^{3} \mathrm{~km}^{3} \mathrm{yr}^{-1}$ in discharge, including the largest in Africa (Supplementary Table 2). A wide size range was sampled, from $<1 \mathrm{~m}$ width (headwaters) to $\sim 10 \mathrm{~km}$ width (mainstem Congo).

\section{Variability of GHG concentrations and fluxes}

The partial pressure of $\mathrm{CO}_{2}\left(p_{\mathrm{CO}_{2}}\right)$ values spanned two orders of magnitude, ranging between 300 and $16,942 \mathrm{ppm}, \mathrm{CH}_{4}$ concentrations varied over five orders of magnitude, ranging between 2 and $62,966 \mathrm{nmoll}^{-1}$, whereas $\mathrm{N}_{2} \mathrm{O}$ spanned three orders of magnitude, ranging between 0.2 and $85.4 \mathrm{nmoll}^{-1}$ (Supplementary Fig. 2). The Congo River was the most variable in GHG concentrations, with distinct differences between streams $\left(<100 \mathrm{~m}\right.$ width) and rivers ( $>100 \mathrm{~m}$ width): $p_{\mathrm{CO}_{2}}$ and $\mathrm{CH}_{4}$ values were higher in streams than rivers, whereas the opposite was observed for $\mathrm{N}_{2} \mathrm{O}$ and oxygen saturation level

\footnotetext{
${ }^{1}$ Université de Liège, Unité d'Océanographie Chimique, Institut de Physique (B5), B-4000, Belgium. ${ }^{2}$ Katholieke Universiteit Leuven, Department of Earth and Environmental Sciences, Celestijnenlaan 200E, B-3001 Leuven, Belgium. ${ }^{3}$ Kenyatta University, Department of Zoological Sciences,

PO Box 16778-80100, Mombasa, Kenya. ${ }^{4}$ Geosciences Environnement Toulouse UMR 5563 \& UR 234 IRD, Université Paul-Sabatier, Avenue Edouard Belin 14, F-31400 Toulouse, France. ${ }^{5}$ Kenya Marine and Fisheries Research Institute, PO Box 81651, Mombasa-80100, Kenya.

*e-mail: alberto.borges@ulg.ac.be
} 


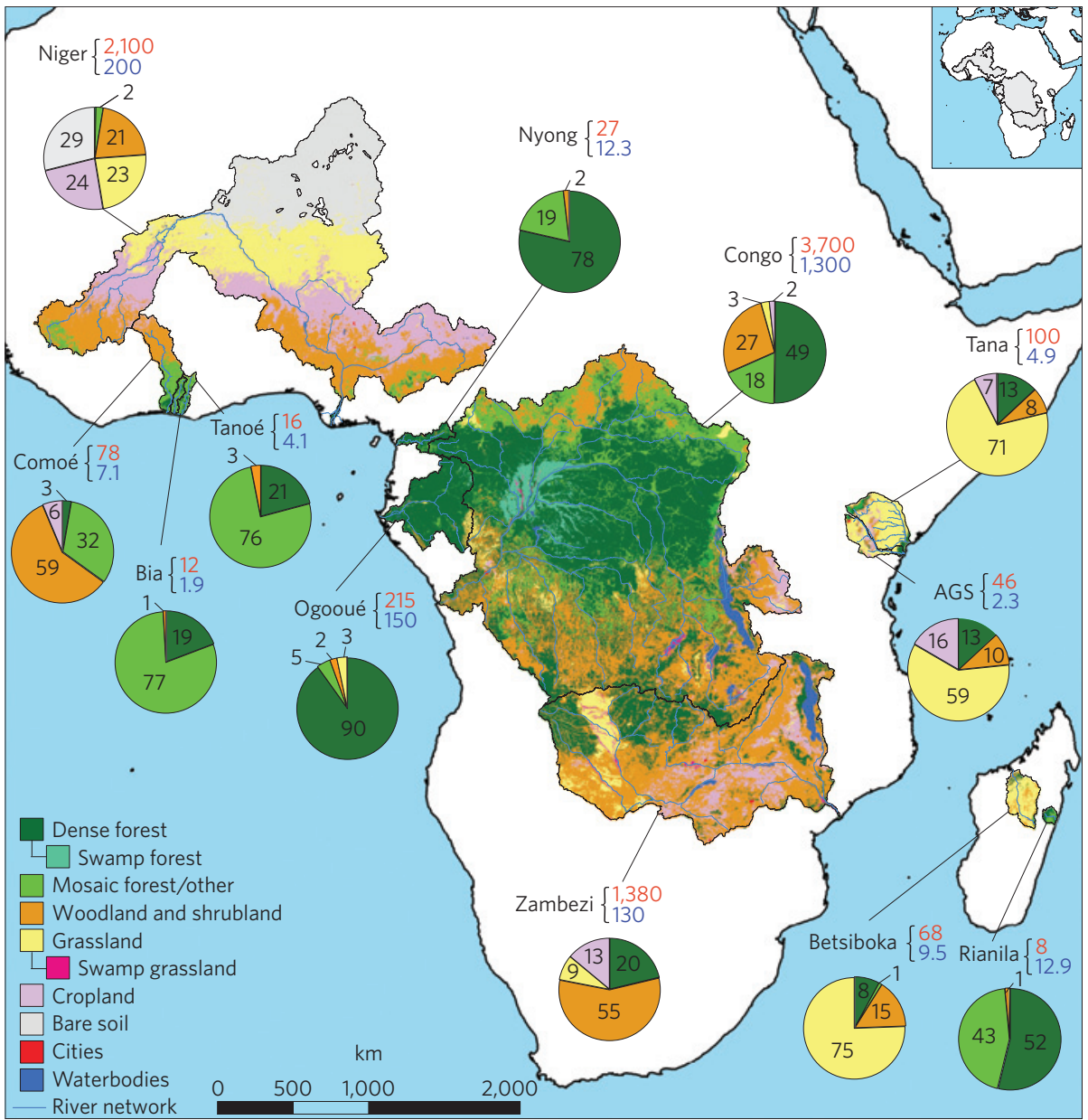

Figure 1 | The 12 studied rivers cover a wide range of discharge, catchment size and land cover. The red numbers correspond to the catchment surface area $\left(10^{3} \mathrm{~km}^{2}\right)$ and the blue numbers correspond to the annual freshwater discharge $\left(\mathrm{km}^{3} \mathrm{yr}^{-1}\right)$. Refer to Methods for data sources. AGS,

Athi-Galana-Sabaki River.

$\left(\% \mathrm{O}_{2}\right)$ (Supplementary Fig. 2). The overall average $p_{\mathrm{CO}_{2}}$ and $\mathrm{CH}_{4}$ in rivers was $6,415 \mathrm{ppm}$ and $2,205 \mathrm{nmoll}^{-1}$, respectively, corresponding to large over-saturation of surface waters with respect to atmospheric equilibrium of $\mathrm{CO}_{2}$ and $\mathrm{CH}_{4}$ (on average $\sim 395$ ppm and $\sim 2 \mathrm{nmoll}^{-1}$, respectively). The $\mathrm{N}_{2} \mathrm{O}$ values oscillated between under- and over-saturation, with an overall average of $9.2 \mathrm{nmoll}^{-1}$, only slightly above the atmospheric equilibrium of $\sim 6.6 \mathrm{nmoll}^{-1}$.

The fluxes were computed from the gas transfer velocity $(k)$ using two approaches. The Aufdenkampe et al. (Auf) approach ${ }^{2}$ relies on constant $k$ values across basins separated into streams and rivers ( $<100 \mathrm{~m}$ and $>100 \mathrm{~m}$ width, respectively). The Raymond et al. (Ray) approach ${ }^{3}$ uses basin-specific $k$ values computed from hydraulic equations and basin characteristics. We present both estimates to provide a range of flux values, allowing a comparison with published fluxes. An error analysis is provided in the Supplementary Methods and Methods. Among river systems, the air-water $\mathrm{CO}_{2}$ fluxes computed with the Auf approach $\left(\mathrm{FCO}_{2 \mathrm{Auf}}\right)$ ranged between $186 \pm 9$ and $1,149 \pm 53 \mathrm{mmol} \mathrm{m}^{-2} \mathrm{~d}^{-1}$, the air-water $\mathrm{CH}_{4}$ fluxes $\left(\mathrm{FCH}_{4 \text { Auf }}\right)$ ranged between $0.5 \pm 0.1$ and $18 \pm 1 \mathrm{mmol} \mathrm{m}^{-2} \mathrm{~d}^{-1}$, and the air-water $\mathrm{N}_{2} \mathrm{O}$ fluxes $\left(\mathrm{FN}_{2} \mathrm{O}_{\text {Auf }}\right)$ ranged between $2.0 \pm 0.1$ and $16 \pm 1 \mu \mathrm{mol} \mathrm{m}^{-2} \mathrm{~d}^{-1}$ (Supplementary Table 3). The fluxes computed using the Ray approach were $\sim 1.34$ times higher, as it accounts for lower-order streams that are more turbulent and have higher $k$ values. The average $\mathrm{FCO}_{2}$ for all rivers was 11 times higher than $\mathrm{FCH}_{4}$ (in $\mathrm{CO}_{2} \mathrm{e}$ ) and 273 times higher than $\mathrm{FN}_{2} \mathrm{O}$ (in $\mathrm{CO}_{2} \mathrm{e}$ ). For individual basins, the $\mathrm{FCO}_{2}: \mathrm{FCH}_{4}$ ratio ranged between 4 (Zambezi) and 39 (Tana). This is in contrast to other concurrent $\mathrm{FCO}_{2}, \mathrm{FCH}_{4}$ and $\mathrm{FN}_{2} \mathrm{O}$ estimates in temperate rivers (Supplementary Table 4), where $\mathrm{FCO}_{2}: \mathrm{FCH}_{4}$ ratios are higher (between 9 and 411, average 108) and $\mathrm{FCO}_{2}: \mathrm{FN}_{2} \mathrm{O}$ ratios are lower (between 10 and 71, average 35). This reflects the less extensive flooded areas in these temperate rivers (floodplains promote $\mathrm{FCH}_{4}$ compared to $\mathrm{FCO}_{2}$ ), and higher inputs of fertilizer- or wastewaterderived nitrogen, which promote $\mathrm{FN}_{2} \mathrm{O}$ (ref. 5) compared to $\mathrm{FCO}_{2}$.

The $\mathrm{FCO}_{2 \text { Ray }}$ we report were 1.1-4.7 times (on average 2.6 times) higher than those given by Raymond et $a l^{3}$ for the same basins (Supplementary Fig. 3), suggesting that the reliance of the latter on a very limited African $p_{\mathrm{CO}_{2}}$ database resulted in underestimating the riverine $\mathrm{FCO}_{2}$ for the African continent. When comparing the surface-area-integrated $\mathrm{FCO}_{2}$ per basin (Supplementary Table 3) to the flux of total organic C (TOC) and dissolved inorganic C (DIC) to the ocean for the Congo, the Zambezi and the Tana (data are unavailable for other rivers sampled), $\mathrm{FCO}_{2}$ was, respectively, 8.6, 2.1 and 9.9 times higher than the TOC+DIC export to the ocean, or 13.3, 16.5 and 23.0 times higher than the TOC export to the ocean. By comparison, in the Amazon River, the total $\mathrm{FCO}_{2}$ is 6.6 and 13.1 times higher than the TOC+DIC and TOC export to the ocean ${ }^{14}$. This clearly highlights the significance of vertical $C$ fluxes from inland waters to the atmosphere.

\section{Regional and global significance of GHG fluxes}

The $\mathrm{FCO}_{2}$ integrated for all SSA rivers ranged between $0.27 \pm 0.05$

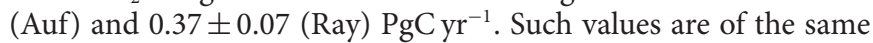


a

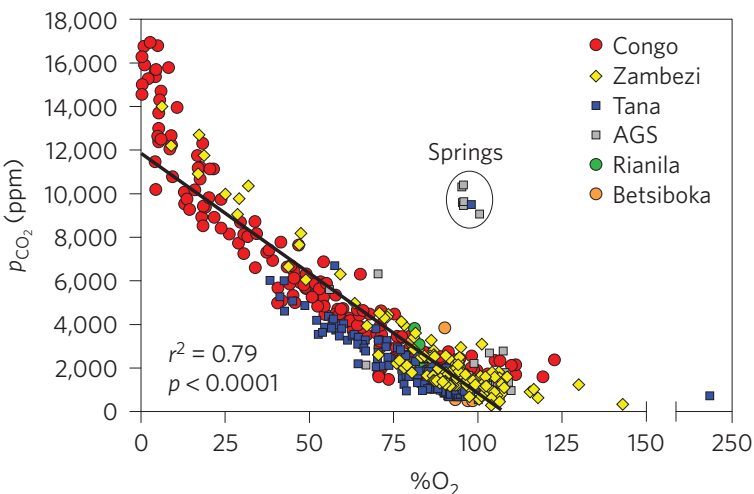

c

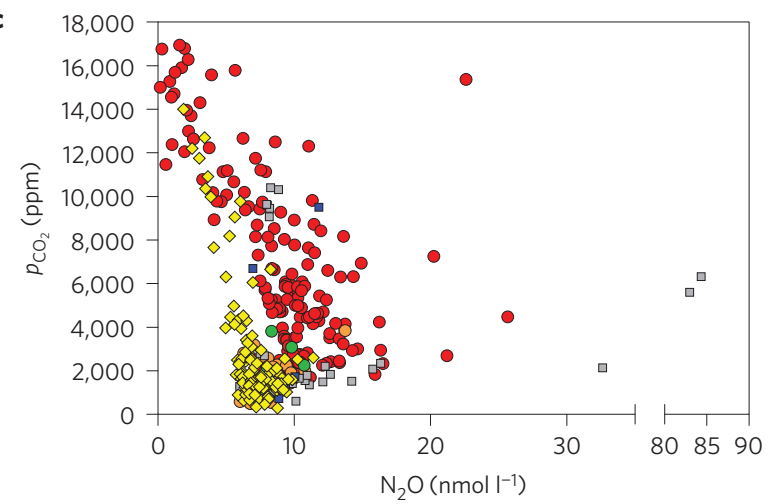

b

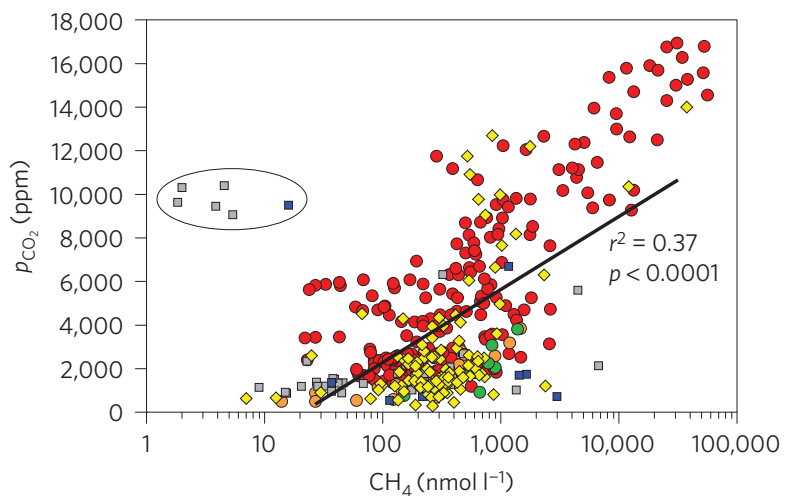

d

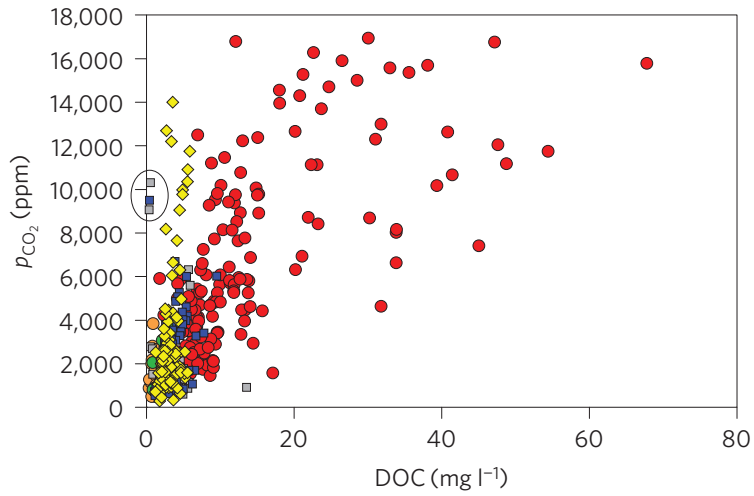

Figure 2 | Complex interplay of biogeochemical processes is revealed by $\mathrm{GHG} \mathrm{H}$ property-property relations. $\mathrm{pCO}_{2}$ as functions of $\% \mathrm{O}_{2}$ (a), log $\mathrm{CH}_{4}$ (b), $\mathrm{N}_{2} \mathrm{O}(\mathbf{c})$ and DOC (d) in six African river systems. The encircled data points correspond to water from springs that are enriched in $\mathrm{CO}_{2}$, depleted in $\mathrm{CH}_{4}$ and DOC owing to bacterial removal in groundwaters and at $\mathrm{O}_{2}$ saturation owing to rapid equilibration with the atmosphere. Lines correspond to a linear regression fit.

order of magnitude as the integrated $\mathrm{FCO}_{2}$ for the Amazon River of $0.47 \mathrm{PgC} \mathrm{yr}^{-1}$ (ref. 14), although the latter estimate included wetlands that accounted for $86 \%$ of flooded land whereas river channels only occupied $14 \%$ (ref. 13). The $\mathrm{FCH}_{4}$ integrated for all rivers in SSA ranged between $2.9 \pm 0.1$ (Auf) and $3.9 \pm 0.1$ (Ray) $\mathrm{TgC}_{\mathrm{yr}}{ }^{-1}$. This is roughly five times higher than the $\mathrm{FCH}_{4}$ recently attributed for all tropical rivers $\left(0.7 \mathrm{TgC}^{-1}\right)$ in a recent data synthesis ${ }^{4}$, where, in the absence of empirical data from the tropics, the average $\mathrm{CH}_{4}$ flux from temperate rivers was upscaled. The sum of integrated $\mathrm{FCO}_{2}$ and $\mathrm{FCH}_{4}$ ranged between $0.29 \pm 0.05$ (Auf) and $0.39 \pm 0.07$ (Ray) $\mathrm{PgCO}_{2} \mathrm{e} \mathrm{yr}^{-1}$. These values are highly significant when compared to other fluxes at the scale of the African continent given by the most recent overarching synthesis ${ }^{8}$, such as the $\mathrm{C}$ emission from fossil fuel $\left(\sim 1.25 \mathrm{PgC} \mathrm{yr}^{-1}\right)$, terrestrial net ecosystem production (NEP) (1.2-2.9 $\left.\mathrm{PgC} \mathrm{yr}^{-1}\right)$, or TOC+DIC export to the ocean $\left(0.06 \mathrm{PgC} \mathrm{yr}^{-1}\right)$. The emission of $\mathrm{CO}_{2}$ and $\mathrm{CH}_{4}$ in $\mathrm{CO}_{2}$ e from SSA rivers would thus balance two-thirds of the reported net $\mathrm{C}$ sink for continental Africa $\left(0.6 \pm 0.6 \mathrm{PgC} \mathrm{yr}^{-1}\right.$; ref. 8). Note that the net $\mathrm{C}$ sink estimate of the latter did not account for the fluxes from inland waters.

We propose that our emission estimates of $\mathrm{CO}_{2}$ and $\mathrm{CH}_{4}$ from SSA rivers may be conservative for two reasons. First, the $\mathrm{FCH}_{4}$ values correspond only to diffusive emissions and do not account for $\mathrm{CH}_{4}$ ebullition, which can be highly significant in tropical aquatic environments ${ }^{17-19}$. Based on floating chamber flux measurements in the Congo and Zambezi rivers $(n=68)$, we found $\mathrm{CH}_{4}$ ebullition rates to be on average 0.25 times the diffusive $\mathrm{CH}_{4}$ flux (Supplementary Fig. 4). This compares well with data from six Amazon river channels, where $\mathrm{CH}_{4}$ ebullition was 0.33 times the diffusive $\mathrm{CH}_{4}$ flux ${ }^{19}$. Applying a factor of 0.25 to estimate the $\mathrm{CH}_{4}$ ebullition, the sum of integrated $\mathrm{FCO}_{2}$ and $\mathrm{FCH}_{4}$ would then range between $0.30 \pm 0.05$ (Auf) and $0.40 \pm 0.07$ (Ray)
$\mathrm{PgCO}_{2} \mathrm{e} \mathrm{yr}^{-1}$. Second, our estimates do not account for extensive tropical wetlands, which in the Amazon are known to show $\mathrm{CH}_{4}$ fluxes two orders of magnitude higher than river channels ${ }^{17}$. The Congolese 'Cuvette Centrale', with a flooded surface area of $360 \times 10^{3} \mathrm{~km}^{2}$ (ref. 20), is the second largest tropical wetland area after the Amazon. The sum of $\mathrm{FCO}_{2}$ and $\mathrm{FCH}_{4}$ from the 'Cuvette Centrale' would correspond to $0.48 \pm 0.08 \mathrm{PgCO}_{2} \mathrm{e} \mathrm{yr}^{-1}$ (based on the scaling of a subset of fluxes from the rivers, streams and navigation channels draining the 'Cuvette Centrale' and computed with the $k$ recommended for flooded areas ${ }^{2}$ ). The above $\mathrm{FCH}_{4}$ estimate for the 'Cuvette Centrale' does not include the ebullition of $\mathrm{CH}_{4}$; using a reported ebullition:diffusion ratio of 0.73 for tropical wetlands ${ }^{18}$ would bring the total $\mathrm{FCO}_{2}$ and $\mathrm{FCH}_{4}$ from SSA rivers and wetlands to range between $0.85 \pm 0.10$ (Auf) and $0.95 \pm 0.11$ (Ray) $\mathrm{PgCO}_{2} \mathrm{e} \mathrm{yr}^{-1}$. These fluxes are significant beyond the African continental scale, considering that the global net $\mathrm{CO}_{2}$ sink is at present estimated at 1.5 and $2.0 \mathrm{PgC} \mathrm{yr}^{-1}$ for the oceans and the terrestrial biosphere, respectively ${ }^{7}$.

\section{Processes underlying GHG dynamics}

Although it is crucial to quantify GHG fluxes, unravelling the underlying processes is equally important. This can be attempted with a correlation analysis with other biogeochemical variables and catchment characteristics. The $\mathrm{p}_{\mathrm{CO}_{2}}$ data were well correlated to $\% \mathrm{O}_{2}$ and to the $\log$ of $\mathrm{CH}_{4}$ (Fig. 2a,b), suggesting that the dynamics of the three variables were driven by net heterotrophy ${ }^{1}$. The lowest $\mathrm{N}_{2} \mathrm{O}$ values (below atmospheric equilibrium) were observed at the highest $p_{\mathrm{CO}_{2}}$ (Fig. 2c) and lowest $\% \mathrm{O}_{2}$ levels (Supplementary Fig. 5), suggesting the removal of $\mathrm{N}_{2} \mathrm{O}$ by denitrification, as also reported in the Amazon floodplains ${ }^{21}$. No distinct relationship could be established between $\mathrm{N}_{2} \mathrm{O}$ and either nitrate $\left(\mathrm{NO}_{3}{ }^{-}\right)$, ammonium $\left(\mathrm{NH}_{4}^{+}\right)$, or dissolved inorganic nitrogen $\left(\mathrm{DIN}=\mathrm{NO}_{3}^{-}+\mathrm{NH}_{4}^{+}\right)$ 


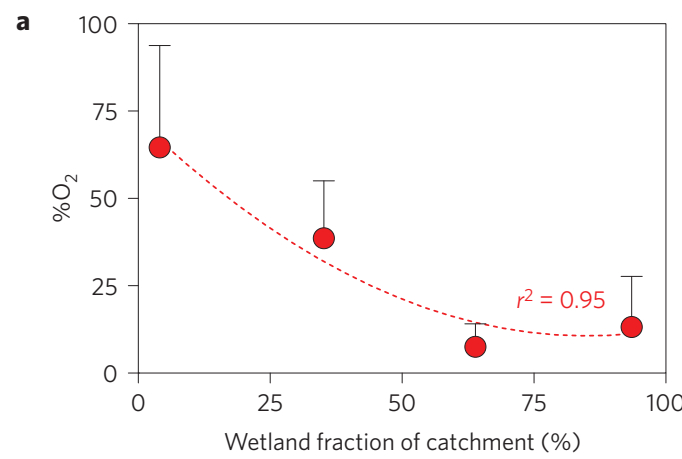

C

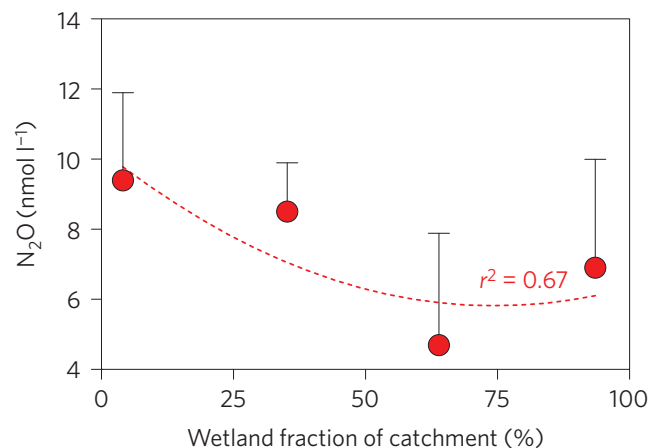

b

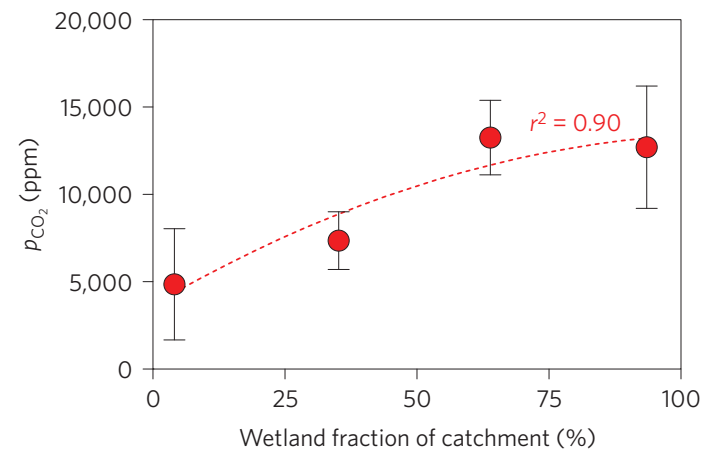

d

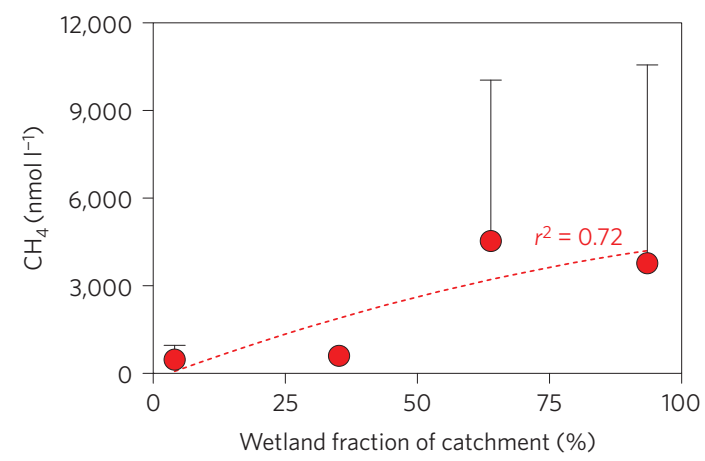

Figure 3 | Wetland presence drives the pattern of $\mathrm{GHG}$ and $\mathrm{O}_{2}$ in the Congo River. $\% \mathrm{O}_{2}(\mathbf{a}), \mathrm{pCO}_{2}(\mathbf{b}), \mathrm{N}_{2} \mathrm{O}(\mathbf{c})$ and $\mathrm{CH}_{4}(\mathbf{d})$ in 46 rivers of the $\mathrm{Congo}$ basin as a function of wetland fraction of catchment surface. Data were bin-averaged in intervals of $25 \%$. Two extreme $\mathrm{CH}_{4}$ values ( $>25,000$ nmol $\mathrm{I}^{-1}$ ) were removed from the analysis. Error bars show mean \pm s.d. Lines correspond to a second-degree polynomial fit.

(Supplementary Fig. 5), unlike in some temperate rivers ${ }^{5}$. In three of the sampled rivers, data sets from long-term fixed station monitoring showed a positive relationship between $\mathrm{N}_{2} \mathrm{O}$ and $\mathrm{NO}_{3}{ }^{-}$ (Supplementary Fig. 6). The sampled rivers had relatively low DIN values $^{22}$, as fertilizer use is minimal within the catchments studied ${ }^{23}$, and samples were not directly impacted by wastewaters from major cities; the only exception being the upper reaches of the Athi River, which are strongly influenced by wastewater inputs from Nairobi ${ }^{22}$ and where the highest $\mathrm{N}_{2} \mathrm{O}$ concentrations were recorded (Supplementary Fig. 3).

No relationship could be established between GHGs and elevation or water temperature (Supplementary Fig. 7). There was a general positive relationship between $p_{\mathrm{CO}_{2}}$ and dissolved organic C (DOC) (Fig. 2d) that has been used to infer the role of terrestrial organic matter inputs in sustaining net heterotrophy and $\mathrm{CO}_{2}$ production within inland waters ${ }^{9}$, although this can also be interpreted as an indication of concurrent $\mathrm{DOC}$ and $\mathrm{CO}_{2}$ inputs from soils or wetlands. The $p_{\mathrm{CO}_{2}}$ in the Congo River levelled off for DOC concentrations $>15 \mathrm{mgl}^{-1}$, which may indicate a limitation of bacterial growth (and subsequent $\mathrm{CO}_{2}$ production) by the low $\mathrm{pH}$ in these very acidic organic environments (so called 'black waters', with $\mathrm{pH}$ between 3.6 and 5.9 and averaged 4.4), $\mathrm{O}_{2}$ availability $\left(\% \mathrm{O}_{2}\right.$ ranged between $0.3 \%$ and $93.5 \%$ and averaged 23.4\%; Supplementary Fig. 8), or phosphorus availability as reported in other tropical black water rivers ${ }^{24}$.

Concentrations of GHGs increased as the wetland fraction of the catchment surface increased for individual catchments (Congo River) and across river systems (Figs 3 and 4). In the Congo River, $\mathrm{P}_{\mathrm{CO}_{2}}$ and $\mathrm{CH}_{4}$ were positively related to wetland fraction, whereas $\% \mathrm{O}_{2}$ and $\mathrm{N}_{2} \mathrm{O}$ were negatively related to the latter (Fig. 3). The $\mathrm{CO}_{2}$, $\mathrm{CH}_{4}$ and $\% \mathrm{O}_{2}$ patterns in the Congo tributaries along a $1,700 \mathrm{~km}$ river stretch (Supplementary Fig. 9) and in the Zambezi River ${ }^{25}$ also follow the presence of wetlands. Similarly, a relationship between $\mathrm{CH}_{4}, p_{\mathrm{CO}_{2}}$ and $\% \mathrm{O}_{2}$ with wetland fraction was also found across river systems (Fig. 4), consistent with findings in the Amazon basin, where $\mathrm{CO}_{2}$ emissions from wetland lakes and river channels have been attributed to organic $\mathrm{C}$ from wetlands ${ }^{11-13}$ that also sustain intense $\mathrm{CH}_{4}$ evasion ${ }^{17}$.

However, basins that are virtually devoid of wetlands, such as the Tana $(<0.5 \%$ of the catchment), were also found to be sources of $\mathrm{CO}_{2}$, although admittedly lower than other SSA rivers. This suggests that part of the $\mathrm{CO}_{2}$ emissions from SSA rivers are partly sustained by upland biomass. The increase of $\mathrm{CO}_{2}$ and $\mathrm{CH}_{4}$ and decrease of $\% \mathrm{O}_{2}$ in the Congo tributaries also follow the downstream increase of aboveground biomass and of the relative dense forest cover (Supplementary Figs 9 and 10). These patterns were also observed across river systems, although the Rianila catchment deviated from the general pattern owing to much steeper slopes within the basin (Supplementary Fig. 11). This highlights the role of relief, whereby gentle slopes increase water residence time and the extent of flooded areas, and steeper slopes enhance $k$, which drives dissolved GHG concentrations closer to saturation ${ }^{26}$. Precipitation has been previously used to model river $\mathrm{CO}_{2}$ regionally ${ }^{26}$. We indeed found a positive relationship between $p_{\mathrm{CO}_{2}}$ and $\mathrm{CH}_{4}$ and precipitation across SSA rivers, with the exception of the two Malagasy rivers (Supplementary Fig. 11). For the Rianila, this might also be related to the steeper slope. In the Betsiboka, nearly all of the yearly precipitation occurs from December to March, the rest of the year being extremely dry, leading to vegetation typical of a semi-arid climate. This suggests that models to predict $p_{\mathrm{CO}_{2}}$ from precipitation should also account for the regional differences in seasonal patterns.

\section{Lateral inputs versus in situ respiration as $\mathrm{CO}_{2}$ drivers}

In addition to our GHG concentration measurements, we acquired 812 aquatic community respiration $(R)$ data (Supplementary Fig. 12). The $R$ values ranged between 0.3 and $404.0 \mathrm{mmolC} \mathrm{m}^{-3} \mathrm{~d}^{-1}$, with a median of $20.0 \mathrm{mmolC} \mathrm{m}^{-3} \mathrm{~d}^{-1}$, which is close to the median value of pelagic bacterial respiration reported in a recent data synthesis in tropical inland waters ${ }^{27}$. On individual paired mea- 


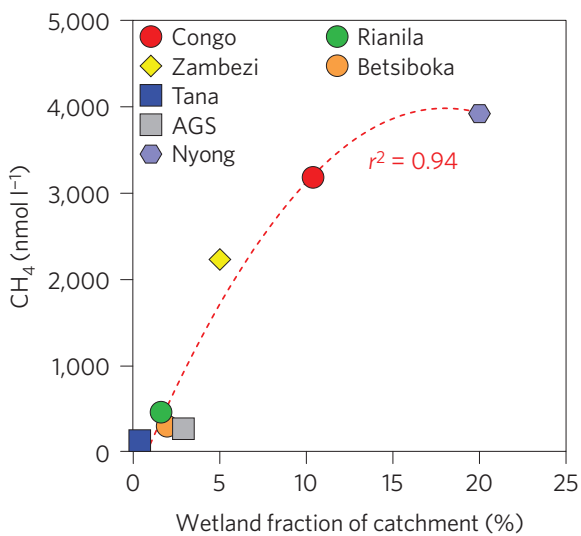

b

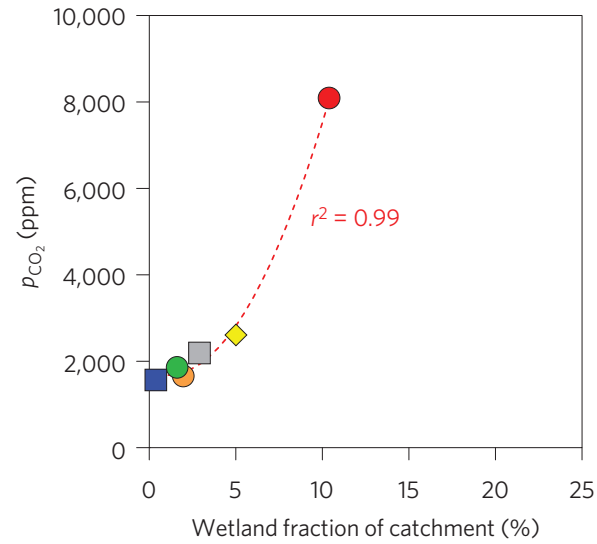

c

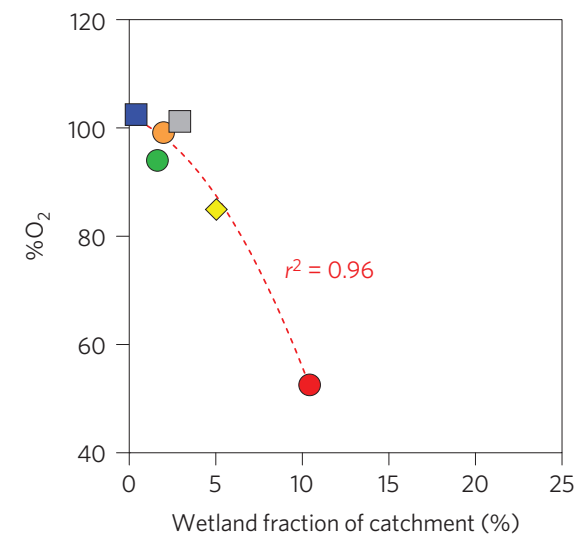

Figure 4 | Wetland presence drives the pattern of $\mathrm{CO}_{2}$ and $\mathrm{CH}_{4}$ concentrations across sub-Saharan African Rivers. $\mathrm{p}_{\mathrm{CO}_{2}}(\mathbf{a}), \mathrm{CH}_{4}(\mathbf{b})$ and $\% \mathrm{O}_{2}$ (c), as a function of the wetland fraction of catchment surface (\%) in seven African rivers. Only the data sets that capture spatial variations were included in the analysis (excluding fixed time series in the mainstem of rivers). Lines correspond to a second-degree polynomial fit.

surements, the $\mathrm{FCO}_{2}$ was on average 8 times (Auf) to 12 times (Ray) higher than vertically integrated $R(n=602)$. The median $R$ was $99.4 \mathrm{mmolC} \mathrm{m}^{-2} \mathrm{~d}^{-1}$, which, when upscaled to all SSA rivers, can account only for $11 \%$ of the $\mathrm{FCO}_{2}\left(0.27 \mathrm{PgC} \mathrm{yr}^{-1}\right)$. Although benthic respiration was not measured during our study, using the average value from a recent data synthesis for tropical rivers and streams (50.8 $\mathrm{mmolC} \mathrm{m}^{-2} \mathrm{~d}^{-1}$; ref. 28), we find that pelagic and benthic $R$ combined still account for only $<14 \%$ of the $\mathrm{FCO}_{2}$. Furthermore, these estimates do not account for pelagic and benthic aquatic primary production, which would decrease the dissolved $\mathrm{CO}_{2}$ concentration. These calculations imply that lateral inputs of $\mathrm{CO}_{2}$ from soils, groundwaters and wetlands would be the largest contributors of the $\mathrm{CO}_{2}$ emitted from rivers and streams.
Implications for understanding global C fluxes

Large $\mathrm{CO}_{2}$ fluxes from inland waters have significant implications for our understanding of overall $\mathrm{C}$ fluxes and cycling at the landscape or catchment scale. The $\mathrm{CO}_{2}$ emitted to the atmosphere from inland waters can be considered as a component of the respiration of upland and wetland vegetation, whether it is related to lateral transport of soil/wetland $\mathrm{CO}_{2}$ (that is, respiration taking place in terrestrial or wetland habitats) or lateral transport of soil or wetland DOC and POC that is mineralized to $\mathrm{CO}_{2}$ within the aquatic domain. Hence, the lateral transport of $\mathrm{C}$ from the upland terrestrial biosphere and wetlands to inland waters and its subsequent emission to the atmosphere offsets the estimates of terrestrial NEP. Furthermore, lateral transport of soil DOC leads to an underestimation of NEP based on biomass accumulation techniques, whereas the lateral transport of soil $\mathrm{CO}_{2}$ leads to an overestimation of NEP derived from atmospheric measurements (eddy-covariance or flux towers). The significant $\mathrm{FCO}_{2}$ from African inland waters at the continental scale is particularly important in the context of the mitigation of, and accounting for, GHG emissions, as $\mathrm{C}$ emissions related to tropical deforestation are only partially offset by $\mathrm{C}$ sequestration from forest regrowth ${ }^{29}$. Accounting for the additional $\mathrm{C}$ emissions from inland waters could further offset this balance. Alternatively, if most of the $\mathrm{CO}_{2}$ emissions from SSA river channels are derived from wetland $\mathrm{C}$, the net balance would be nearly neutral as it is balanced by the atmospheric $\mathrm{CO}_{2}$ fixation by the emerged vegetation, as shown in the Amazon lowland areas ${ }^{11-13}$. Untangling the relative contributions of wetland and upland $\mathrm{C}$ in sustaining $\mathrm{CO}_{2}$ and $\mathrm{CH}_{4}$ emissions from inland waters is essential to better understand the role of tropical inland waters in the global $\mathrm{C}$ cycle and related potential feedbacks on a warming climate. Our results in SSA rivers show that this relative contribution is variable both within individual catchments and across catchments.

\section{Methods}

Methods and any associated references are available in the online version of the paper.

Received 19 February 2015; accepted 10 June 2015; published online 20 July 2015

\section{References}

1. Cole, J. J. et al. Plumbing the global carbon cycle: Integrating inland waters into the terrestrial carbon budget. Ecosystems 10, 171-184 (2007).

2. Aufdenkampe, A. K. et al. Riverine coupling of biogeochemical cycles between land, oceans, and atmosphere. Front. Ecol. Environ. 9, 53-60 (2011).

3. Raymond, P. A. et al. Global carbon dioxide emissions from inland waters. Nature 503, 355-359 (2013).

4. Bastviken, D., Tranvik, L. J., Downing, J. A., Crill, P. M. \& Enrich-Prast, A. Freshwater methane emissions offset the continental carbon sink. Science 331, 50 (2011).

5. Baulch, H. M., Schiff, S. L., Maranger, R. \& Dillon, P. J. Nitrogen enrichment and the emission of nitrous oxide from streams. Glob. Biogeochem. Cycles 25, GB4013 (2011).

6. IPCC Climate Change 2013: The Physical Science Basis (eds Stocker, T. F. et al.) (Cambridge Univ. Press, 2013).

7. Le Quéré, C. et al. Global carbon budget 2014. Earth Syst. Sci. Data Discuss. 7, 521-610 (2014).

8. Valentini, R. et al. A full greenhouse gases budget of Africa: Synthesis, uncertainties, and vulnerabilities. Biogeosciences 11, 381-407 (2014).

9. Lapierre, J.-F. \& del Giorgio, P. A. Geographical and environmental drivers of regional differences in the lake $p_{\mathrm{CO}_{2}}$ versus DOC relationship across northern landscapes. J. Geophys. Res. 117, G03015 (2012).

10. Maberly, S. C., Barker, P. A., Stott, A. W. \& De Ville, M. M. Catchment productivity controls $\mathrm{CO}_{2}$ emissions from lakes. Nature Clim. Change 3, 391-394 (2013).

11. Melack, J. M. \& Engle, D. L. An organic carbon budget for an Amazon floodplain lake. Verh. Int. Verein. Limnol. 30, 1179-1182 (2009). 
12. Engle, D. L., Melack, J. M., Doyle, R. D. \& Fisher, T. R. High rates of net primary production and turnover of floating grasses on the Amazon floodplain: Implications for aquatic respiration and regional $\mathrm{CO}_{2}$ flux. Glob. Change Biol. 14, 369-381 (2008).

13. Abril, G. et al. Amazon River carbon dioxide outgassing fuelled by wetlands. Nature 505, 395-398 (2014).

14. Richey, J. E., Melack, J. M., Aufdenkampe, A. K., Ballester, V. M. \& Hess, L. Outgassing from Amazonian rivers and wetlands as a large tropical source of atmospheric $\mathrm{CO}_{2}$. Nature 416, 617-620 (2002).

15. Wang, Z. A. et al. Inorganic carbon speciation and fluxes in the Congo River. Geophys. Res. Lett. 40, 511-516 (2013).

16. Abril, G. et al. Technical Note: Large overestimation of calculated $p_{\mathrm{CO}_{2}}$ in acidic, organic-rich freshwaters. Biogeosciences 12, 67-78 (2015).

17. Melack, J. M. et al. Regionalization of methane emissions in the Amazon Basin with microwave remote sensing. Glob. Change Biol. 10, 530-544 (2004).

18. Bastviken, D. et al. Methane emissions from Pantanal, South America, during the low water season: Toward more comprehensive sampling. Environ. Sci. Technol. 44, 5450-5455 (2010).

19. Sawakuchi, H. O. et al. Methane emissions from Amazonian Rivers and their contribution to the global methane budget. Glob. Change Biol. 20, 2829-2840 (2014).

20. Bwangoy, J.-R. B., Hansen, M. C., Roy, D. P., De Grandi, G. \& Justice, C. O. Wetland mapping in the Congo Basin using optical and radar remotely sensed data and derived topographical indices. Remote Sens. Environ. 114, 73-86 (2010).

21. Richey, J. E., Devol, A. H., Wofy, S. C., Victoria, R. \& Riberio, M. N. G. Biogenic gases and the oxidation and reduction of carbon in Amazon River and floodplain waters. Limnol. Oceanogr. 33, 551-561 (1988).

22. Marwick, T. R. et al. Dynamic seasonal nitrogen cycling in response to anthropogenic N loading in a tropical catchment, Athi-Galana-Sabaki River, Kenya. Biogeosciences 11, 1-18 (2014).

23. Yasin, J. A., Kroeze, C. \& Mayorga, E. Nutrients export by rivers to the coastal waters of Africa: Past and future trends. Glob. Biogeochem. Cycles 24, GB0A07 (2010).

24. Castillo, M. M., Kling, G. W. \& Allan, J. D. Bottom-up controls on bacterial production in tropical lowland rivers. Limnol. Oceanogr. 48, 1466-1475 (2003).

25. Teodoru, C. et al. Spatial variability and temporal dynamics of greenhouse gas $\left(\mathrm{CO}_{2}, \mathrm{CH}_{4}, \mathrm{~N}_{2} \mathrm{O}\right)$ concentrations and fluxes along the Zambezi River mainstem and major tributaries. Biogeosciences 12, 2431-2453 (2015).

26. Butman, D. \& Raymond, P. A. Significant efflux of carbon dioxide from streams and rivers in the United States. Nature Geosci. 4, 839-842 (2011).
27. Amado, A. M. et al. Tropical freshwater ecosystems have lower bacterial growth efficiency than temperate ones. Front. Microbiol. 4, 167 (2014).

28. Cardoso, S. J., Enrich-Prast, A., Pace, M. L. \& Roland, F. Do models of organic carbon mineralization extrapolate to warmer tropical sediments? Limnol. Oceanogr. 59, 48-54 (2014).

29. Pan, Y. et al. A Large and persistent carbon sink in the World's forests. Science 333, 988-993 (2011).

\section{Acknowledgements}

This work was funded by the European Research Council (ERC-StG 240002 AFRIVAL), the Fonds National de la Recherche Scientifique (FNRS, CAKI 2.4.598.07, TransCongo, 14711103), the Belgian Federal Science Policy (BELSPO) (projects COBAFISH SD/AR/05A and EAGLES SD/AR/02A), the Research Foundation Flanders (FWO-Vlaanderen), the Research Council of the KU Leuven, the IRD and INSU/CNRS (SOERE BVET and LIMON projects). The Boyekoli-Ebale-Congo Expedition (2010) was funded by the Belgian Development Cooperation, BELSPO, and Belgian National Lottery. A.V.B. and T.L. are a senior research associate and a postdoctoral researcher at the FNRS, respectively. We are very grateful for help in sampling from A. Yambélé (Direction de la Météorologie Nationale, Central African Republic), J.-D. Mbega (Institut de Recherches Agronomiques et Forestières, Gabon), B. Alhou (Université de Niamey, Niger), F. C. Nyoni and I. Nyambe (University of Zambia, Zambia), B. Ogwoka (Kenya Wildlife Service, Kenya), T. Mambo Baba and E. Tambwe Lukosha (Université de Kisangani, DRC), T. Kisekelwa (Institut Supérieur Pédagogique de Bukavu, DRC), J. N. Wabakanghanzi (Congo Atomic Energy Commission, DRC), C. M. Balagizi (Goma Volcano Observatory, DRC) and J. L. Boeglin (Géosciences Environnement Toulouse - GET, France), for analytical support from M.-V. Commarieu, S. Hoornaert, S. Petrovic (University of Liège (ULg)) and C. Deshmukh (GET), for advice and help in setting up the GCs at ULg from J. Barnes, G. Abril, B. Delille and W. Champenois, and for feedback and input on modelled basin-wide $k$ values from P. Raymond.

\section{Author contributions}

A.V.B. and S.B. conceived and designed the study and coordinated the project and fieldwork. Field data collection was carried out by all co-authors. T.L. carried out the geographical system information (GIS) analysis. A.V.B. drafted the manuscript, which was substantially commented upon and amended by S.B., C.R.T., T.R.M., N.G., T.L. and F.G. All co-authors approved the manuscript.

\section{Additional information}

Supplementary information is available in the online version of the paper. Reprints and permissions information is available online at www.nature.com/reprints.

Correspondence and requests for materials should be addressed to A.V.B.

\section{Competing financial interests}

The authors declare no competing financial interests. 


\section{Methods}

We acquired 1,880 data for $\mathrm{CH}_{4}, 1,625$ data for $\mathrm{N}_{2} \mathrm{O}$ and 693 data for $p_{\mathrm{CO}_{2}}$ from June 2006 to September 2014 in 12 river basins (Supplementary Table 1). The dissolved gases were measured with a uniform method based on the headspace technique, either directly in the field by infrared gas analysis (IRGA; for $\mathrm{CO}_{2}$ ), or on return in the laboratory by gas chromatography (GC; for $\mathrm{CH}_{4}$ and $\mathrm{N}_{2} \mathrm{O}$ ). Our analysis excludes $p_{\mathrm{CO}_{2}}$ data computed from $\mathrm{pH}$ and total alkalinity, because of strong biases due to the interference from organic acids, in particular in organic C rich black waters ${ }^{15,16}$.

Sampling and field measurements. Two approaches were used during this study (Supplementary Table 1). First, a 'survey' approach aimed at sampling the mainstem of a river network over the longest possible stretch, as well as a maximum number of contributing tributaries, typically during a short period of time (2-60 d). In most cases, the surveys were done by car, with sampling from boats, bridges, or from the shore. In other cases, travel and sampling were carried out by boat (Congo River). Second, a 'monitoring' approach was applied at various fixed stations during a $1-2$ yr period, with sampling taking place at monthly or fortnightly intervals in the mainstem of one or several rivers. The two approaches are highly complementary as the 'survey' approach provides a snapshot of the spatial variability, whereas the 'monitoring' approach provides the range of seasonal variability, but with little or no description of the spatial heterogeneity.

Water was collected with a Niskin bottle just below the surface $(<0.5 \mathrm{~m})$ and two serum bottles $(50 \mathrm{ml})$ for the determination of $\mathrm{CH}_{4}$ and $\mathrm{N}_{2} \mathrm{O}$ were filled through tubing, allowed to overflow, poisoned with a saturated solution of $\mathrm{HgCl}_{2}$ (50-100 $\mu \mathrm{l})$, sealed with butyl stoppers, crimped with aluminium caps, and stored at ambient temperature in the dark. Samples for the determination of $p_{\mathrm{CO}_{2}}$ were directly collected in surface waters in four plastic $60 \mathrm{ml}$ syringes and $30 \mathrm{ml}$ of sample water was equilibrated with $30 \mathrm{ml}$ of ambient air (5-10 min of vigorous shaking). The $p_{\mathrm{CO}_{2}}$ in ambient air and in the equilibrated gas phase were determined with a portable IRGA, from which the in situ $p_{\mathrm{CO}_{2}}$ was computed using the temperature values in situ and in the equilibrated water (that is, in the syringe), and Henry's constant. The IRGAs were calibrated with $\mathrm{N}_{2}$ and a $\mathrm{CO}_{2}: \mathrm{N}_{2}$ commercial mixture (Air Liquide Belgium) with a mixing ratio of $1,017 \mathrm{ppm}$ of $\mathrm{CO}_{2}$ (PP Systems EGM-4 and Li-Cor Li-820) or with $\mathrm{N}_{2}$ and a suite of $\mathrm{CO}_{2}: \mathrm{N}_{2}$ commercial mixtures (Air Liquide Belgium) with mixing ratios of 388, 813, 3,788 and $8,300 \mathrm{ppm} \mathrm{CO}_{2}$ (Li-Cor Li-840). The Li-840 was used on the Congo in December 2013 and June 2014, the EGM-4 was used on the Congo in December 2012 and September 2013 and on the Zambezi, whereas the Li-820 was used on the Malagasy, Tana and Athi-Galana-Sabaki rivers. In the Congo in March 2013, the headspace was injected in pre-evacuated $12 \mathrm{ml}$ Exetainer (Labco) vials and the $\mathrm{CO}_{2}$ content was analysed by GC back in the laboratory (see hereafter). The overall precision of $p_{\mathrm{CO}_{2}}$ measurements was $\pm 2.0 \%$ ( $n=447$ replications of three to four measurements).

Water temperature, conductivity, $\% \mathrm{O}_{2}$ and $\mathrm{pH}$ were measured in situ with portable field probes calibrated using standard protocols (in most cases using an YSI Proplus probe). Pelagic $R$ was determined from the decrease of $\mathrm{O}_{2}$ in $60 \mathrm{ml}$ biological oxygen demand bottles over $\sim 24 \mathrm{~h}$ incubation periods. The bottles were kept in the dark and close to in situ temperature in a cool box filled with in situ water. The $\mathrm{O}_{2}$ decrease was determined from triplicate measurements at the start and the end of the incubation with an optical $\mathrm{O}_{2}$ probe (YSI ProODO), and $R$ data were converted into carbon units using a respiratory quotient of 1.3 (ref. 30). Samples for the DOC determination were preserved in $40 \mathrm{ml}$ borosilicate vials with polytetrafluoroethylene-coated stoppers and preserved with $\mathrm{H}_{3} \mathrm{PO}_{4}(85 \%)$ after filtration through $0.2 \mu \mathrm{m}$ pore size polyethersulphone (PES) syringe filters. Samples for nitrate $\left(\mathrm{NO}_{3}{ }^{-}\right)$and ammonium $\left(\mathrm{NH}_{4}{ }^{+}\right)$were filtered on a $0.2 \mu \mathrm{m}$ PES syringe filter, collected in $50 \mathrm{ml}$ plastic vials, to which was added $200 \mu \mathrm{l}$ of $\mathrm{H}_{2} \mathrm{SO}_{4} 5 \mathrm{~N}$.

Laboratory chemical analysis. Concentrations of $\mathrm{CH}_{4}$ and $\mathrm{N}_{2} \mathrm{O}$ were determined via the headspace equilibration technique $\left(20 \mathrm{ml} \mathrm{N}_{2}\right.$ headspace in $50 \mathrm{ml}$ serum bottles) and measured by GC (ref. 31) with flame ionization detection (GC-FID) and electron capture detection (GC-ECD) with a SRI 8610C GC-FID-ECD calibrated with $\mathrm{CH}_{4}: \mathrm{CO}_{2}: \mathrm{N}_{2} \mathrm{O}: \mathrm{N}_{2}$ mixtures (Air Liquide Belgium) of 1,10 and $30 \mathrm{ppm} \mathrm{CH}_{4}$ and of 0.2, 2.0 and $6.0 \mathrm{ppm} \mathrm{N}_{2} \mathrm{O}$, and using the solubility coefficients of $\mathrm{CH}_{4}$ (ref. 32) and $\mathrm{N}_{2} \mathrm{O}$ (ref. 33). For the Nyong, the $\mathrm{CH}_{4}$ was determined with a SRI 8610C GC-FID calibrated with $\mathrm{CH}_{4}: \mathrm{N}_{2}$ mixtures (Air Liquide France) of 2, 10 and $100 \mathrm{ppm} \mathrm{CH}_{4}$. For the Ivory Coast rivers, the $\mathrm{CH}_{4}$ was determined by GC-FID, as described elsewhere ${ }^{34}$. The overall precision of measurements was $\pm 3.9 \%$ ( $n=1,057$ duplicate measurements) and $\pm 3.2 \%$ ( $n=900$ duplicate measurements) for $\mathrm{CH}_{4}$ and $\mathrm{N}_{2} \mathrm{O}$, respectively. DOC was analysed according either on a Thermo HiperTOC-isotope ratio mass spectrometer (IRMS) or with an Aurora1030 TOC analyser (OI Analytical) coupled to a Delta V Advantage IRMS, with a precision better than $\pm 5 \%$ (ref. 35). $\mathrm{NO}_{3}{ }^{-}$and $\mathrm{NH}_{4}{ }^{-}$ concentrations were estimated by spectrophotometry, using the dichloroisocyanurate-salicylate-nitroprussiate colorimetric method for $\mathrm{NH}_{4}{ }_{4}$ (ref. 36) and the sulphanilamide colorimetric method for $\mathrm{NO}_{3}{ }^{-}$(refs 37,38). The detection limits were 0.30 and $0.15 \mu \mathrm{moll}^{-1}$ for $\mathrm{NH}_{4}{ }^{+}$and $\mathrm{NO}_{3}{ }^{-}$, respectively.
GHG flux computations. The air-water gas flux $(F)$ was computed according to

$$
F=k \Delta C
$$

where $k$ is the gas transfer velocity and $\Delta C$ is the air-water gas concentration gradient ${ }^{39}$, whereby a positive value corresponds by convention to an emission of gas from the water to the atmosphere.

We used the monthly average corresponding to time of sampling of atmospheric $p_{\mathrm{CO}_{2}}$ from Mount Kenya (Kenya, $-0.05^{\circ} \mathrm{N} 37.80^{\circ} \mathrm{E}$ ), retrieved from the GLOBALVIEW-CO2 database (Carbon Cycle Greenhouse Gases Group of the National Oceanic and Atmospheric Administration (NOAA), Earth System Research Laboratory (ESRL)) and of $\mathrm{N}_{2} \mathrm{O}$ from Mauna Loa (Hawaii,

$19.54^{\circ} \mathrm{N}-155.85^{\circ} \mathrm{E}$ ) from the NOAA/ESRL Chromatograph for Atmospheric Trace Species (CATS) Program. For atmospheric $\mathrm{CH}_{4}$, a constant mixing ratio of $1.9 \mathrm{ppm}$ was used. Atmospheric mixing ratios were converted from dry air to wet air using the water vapour computed from temperature ${ }^{33}$ and into corresponding dissolved concentrations using solubility coefficients of $\mathrm{CO}_{2}(\mathrm{ref} .40), \mathrm{CH}_{4}$ (ref. 32) and $\mathrm{N}_{2} \mathrm{O}$ (ref. 33). Fluxes of $\mathrm{CH}_{4}$ and $\mathrm{N}_{2} \mathrm{O}$ were converted into $\mathrm{CO}_{2}$ equivalents based on the assumption that over a 100-year period the emissions of $1 \mathrm{~kg}$ of $\mathrm{CH}_{4}$ and $1 \mathrm{~kg}$ of $\mathrm{N}_{2} \mathrm{O}$ correspond to $34 \mathrm{~kg}$ and $298 \mathrm{~kg}$ of $\mathrm{CO}_{2}$, respectively ${ }^{6}$. For $k$, we used two approaches. The first approach ${ }^{2}$ uses a constant $k$ normalized to a Schmidt number (Sc) of $600\left(k_{600}\right)$ of $17.2 \mathrm{~cm} \mathrm{~h}^{-1}$ for streams and small rivers ( $<100 \mathrm{~m}$ width), of $12.3 \mathrm{~cm} \mathrm{~h}^{-1}$ for larger rivers ( $>100 \mathrm{~m}$ width) and of $2.4 \mathrm{~cm} \mathrm{~h}^{-1}$ for wetlands. The second approach ${ }^{3}$ provides $k_{600}$ values per river basin corresponding to the average value for the whole river network up to stream order 1 derived from hydraulic equations ${ }^{41}$ and a geographical information system (GIS) description of corresponding input hydraulic variables for each catchment. The Sc numbers of $\mathrm{CO}_{2}, \mathrm{~N}_{2} \mathrm{O}$ and $\mathrm{CH}_{4}$ were computed from water temperature ${ }^{42}$. The $F$ data were aggregated to derive one value per tributary and per river mainstem, before averaging for a given river system. The global $F$ values were computed as averages weighted by water body surface area for each river catchment derived from the percentage of river/stream effective surface area per catchment given in ref. 3. The $F$ values were similarly upscaled to SSA using the river/stream surface areas given in ref. 3.

$\mathrm{FCO}_{2}$ and $\mathrm{FCH}_{4}$ were measured in parallel with a floating chamber in 25 stations in the Congo basin, and 43 stations in the Zambezi basin. The floating chamber consisted of an opaque polyvinyl chloride cylinder $15 \mathrm{~cm}$ in height with a $38 \mathrm{~cm}$ internal diameter holding a volume of $17 \mathrm{l}$, and a $7-\mathrm{cm}$-long underwater skirt. The chamber was deployed for $30 \mathrm{~min}$ and the $\mathrm{p}_{\mathrm{CO}_{2}}$ change inside the chamber was determined directly with an IRGA ( $30 \mathrm{~s}$ logging), whereas $30 \mathrm{ml}$ gas samples for $\mathrm{CH}_{4}$ extracted from inside the chamber at $0,5,10,20$ and $30 \mathrm{~min}$ interval were injected into $50 \mathrm{ml}$ serum vials full of a hyper-saline solution (saturated solution of $\mathrm{NaCl}$ ) for analysis in the laboratory by GC-FID. The fluxes were computed from the temporal change of the partial pressure of the gases, the law of perfect gases, and the geometry of the chamber ${ }^{43}$. The $k_{600}$ of $\mathrm{CO}_{2}$ was computed based on the measured $\mathrm{FCO}_{2}$ and the $p_{\mathrm{CO}_{2}}$ in water and air. Assuming that the $\mathrm{FCO}_{2}$ is exclusively diffusive (that is, that the $\mathrm{CO}_{2}$ ebullition flux is negligible), this $k_{600}$ of $\mathrm{CO}_{2}$ allows the computation of the diffusive $\mathrm{CH}_{4}$ flux from the dissolved $\mathrm{CH}_{4}$ concentration. This in turn allows the computation of the ebullition $\mathrm{CH}_{4}$ flux from the chamber $\mathrm{CH}_{4}$ measurement that captures both ebullition and diffusive $\mathrm{CH}_{4}$ fluxes. Chamber measurements have been assumed to provide biased $k$ values ${ }^{44}$, although often comparing satisfactorily with atmospheric flux measurements $\mathrm{s}^{45,46}$ or infrared imaging of the water surface ${ }^{47}$. The obtained average $k_{600}$ in the Congo $\left(12 \pm 11 \mathrm{~cm} \mathrm{~h}^{-1}\right)$ was not significantly different from the average in the Zambezi $\left(10 \pm 11 \mathrm{~cm} \mathrm{~h}^{-1}\right)$ (unpaired $t$-test, $\left.p<0.05\right)$. These values are distinctly lower than those computed by Raymond et al. ${ }^{3}$ of 22 and $20 \mathrm{~cm} \mathrm{~h}^{-1}$ for the Congo and Zambezi, respectively. This is related to the fact that Raymond et al. ${ }^{3}$ provide $k_{600}$ values for the whole basin, including low-order streams that are more turbulent than higher-order streams and rivers, and characterized by higher $k_{600}$ values $^{41}$. Our data were acquired in the mainstem of rivers and adjacent large tributaries, typically high-order systems. The $k_{600}$ values in the highest stream order in the Congo (9) and Zambezi (8) given by Raymond et al. ${ }^{3}$ are, respectively, 14.5 and $13.3 \mathrm{~cm} \mathrm{~h}^{-1}$-closer to those derived from our chamber measurements. The Congo and Zambezi streams $(<100 \mathrm{~m}$ width) had $k_{600}$ values $\left(11 \pm 10 \mathrm{~cm} \mathrm{~h}^{-1}\right)$ that were not significantly different from those $\left(10 \pm 7 \mathrm{~cm} \mathrm{~h}^{-1}\right)$ in rivers ( $>100 \mathrm{~m}$ width) (unpaired $t$-test, $\left.p<0.05\right)$. These values were close to the $k_{600}$ value for rivers ( $>100 \mathrm{~m}$ width) of $12 \mathrm{~cm} \mathrm{~h}^{-1}$, but lower than the value for streams ( $<100 \mathrm{~m}$ width) of $17 \mathrm{~cm} \mathrm{~h}^{-1}$ given by Aufdenkampfe and colleagues ${ }^{2}$. This reflects the fact that our data in the Congo and Zambezi were obtained in high-order streams, mainly in regions with gentle slopes (lowlands). Nevertheless, the actual accuracy of the chamber $k$ values is irrelevant in the present case because we aimed at determining the $\mathrm{CH}_{4}$ ebullition from the chamber measurements. Yet, these $\mathrm{CH}_{4}$ ebullition estimates are probably conservative and provide underestimates, as for logistical reasons there was no replication of chambers and the deployment was short relative other studies, where it varies between $1 \mathrm{~h}$ (ref. 19) and $24 \mathrm{~h}$ (ref. 18). Indeed, $\mathrm{CH}_{4}$ ebullition is notoriously heterogeneous both in space and time (across different timescales from 
daily to seasonal $)^{48-51}$, and adequately capturing this heterogeneity would require a sampling effort and design incompatible with other aims of our research.

GHG flux error analysis. An error analysis on the GHG flux computation and upscaling was carried out by error propagation of the GHG concentration measurements, the $k$ value estimates, and the estimate of surface areas of river channels to scale the areal fluxes, using a Monte Carlo simulation with 1,000 iterations. The uncertainty on the GHG concentrations led to an uncertainty of areal fluxes of $\pm 1.2 \%, \pm 2.3 \%$ and $\pm 5.2 \%$ for $\mathrm{CO}_{2}, \mathrm{CH}_{4}$ and $\mathrm{N}_{2} \mathrm{O}$, respectively. Whereas no information is available in Aufdenkampe et al. ${ }^{2}$ regarding the uncertainty on $k$ values, the uncertainty on $k$ given by Raymond et al. ${ }^{3}$ was estimated to be $\pm 10.0 \%$, based on the errors on slope and constant of the parameterization ${ }^{41}$. This leads to a cumulated uncertainty of areal fluxes of $\pm 4.6 \%, \pm 4.9 \%$ and $\pm 6.7 \%$ for $\mathrm{CO}_{2}, \mathrm{CH}_{4}$ (diffusive) and $\mathrm{N}_{2} \mathrm{O}$, respectively. Ebullition of $\mathrm{CH}_{4}$ is highly heterogeneous spatially and temporally ${ }^{48-51}$, and it is difficult to quantify this uncertainty. We arbitrarily assigned an uncertainty of $\pm 50 \%$ for $\mathrm{CH}_{4}$ ebullition. This leads to a cumulated uncertainty of total areal fluxes of $\pm 29.4 \%$ for $\mathrm{CH}_{4}$ (diffusive + ebullitive). The river/stream surface areas reported by Raymond $e t \mathrm{al}^{3}{ }^{3}$ were estimated using two different hydraulic equations, which allow one to estimate an uncertainty of $\pm 31.0 \%$. The overall uncertainty of integrated fluxes in river channels is $\pm 18.8 \%, \pm 18.3 \%, \pm 34.2 \%$ and $\pm 19.2 \%$ for $\mathrm{CO}_{2}, \mathrm{CH}_{4}$ (diffusive only), $\mathrm{CH}_{4}$ (diffusive + ebullitive) and $\mathrm{N}_{2} \mathrm{O}$, respectively. The comparison of the wetland mapping of Bwangoy et al. ${ }^{20}$ and of the Africover vegetation map, allows one to evaluate the uncertainty of the surface area of Congolese 'Cuvette Centrale' to $\pm 10 \%$. The overall uncertainty of integrated fluxes in the Congolese 'Cuvette Centrale' is $\pm 7.0 \%$ and $\pm 30.6 \%$ for $\mathrm{CO}_{2}$ and $\mathrm{CH}_{4}$ (diffusive + ebullitive), respectively.

Other sources of uncertainty that are not straightforward to quantify relate to seasonal and spatial representativeness. For all spatial surveys, we paid particular attention to cover the widest possible spectrum of systems from mainstem to headwaters, to capture spatial variations in the most comprehensive way given logistical constraints. Data from all basins cover different hydrologic conditions and average fluxes capture seasonality. Spatial and seasonal variations have been presented and discussed for some basins in site-specific studies ${ }^{22,25,34,52-54}$.

GIS analysis of catchment characteristics. Mean slope and drainage area were extracted from the HYDRO1K global hydrologic data set ${ }^{55}$. The fractional land cover type of the watershed was extracted from the Global Land Cover (GLC) 2000 database of Africa ${ }^{56}$. In total, 27 different land sub-classes are defined in the GLC database, taking into account the dominant vegetation class (namely trees, shrubs and grasses), phenology, seasonality, flooding regime and altitude. These sub-classes were aggregated in seven first-level classes based on vegetation structural categories: dense forest, mosaic forest/other, woodlands and shrublands, grasslands, agricultural lands, bare soils and others (water bodies, urban). Aboveground biomass in $\mathrm{Mg} \mathrm{km}^{-2}\left(\mathrm{Mg}=10^{9} \mathrm{~g}\right)$ was extracted from the Woods Hole Research Center (WHRC) pantropical national level C stock data set ${ }^{57}$. The extent of wetland and floodplain areas was extracted from the Global Lakes and Wetlands Database ${ }^{58}$, except for the Nyong ${ }^{59}$ and the Tana (Omengo, F. O. Based on A GIS Analysis of Landsat Images). Annual precipitation was extracted from the WorldClim Global Climate Database ${ }^{60}$.

Data availability. The full data set of $\mathrm{CO}_{2}, \mathrm{CH}_{4}$ and $\mathrm{N}_{2} \mathrm{O}$ concentrations is available as Supplementary Information.

Data sources. Several publicly available data sources were used: HYDRO1K global hydrologic data set: https://lta.cr.usgs.gov/HYDRO1K GLC 2000 database of Africa:

http://forobs.jrc.ec.europa.eu/products/glc2000/products.php WHRC pantropical national level C stock data set:

http://www.whrc.org/mapping/pantropical/carbon_dataset.html Global Lakes and Wetlands Database:

https://www.worldwildlife.org/pages/global-lakes-and-wetlands-database WorldClim-Global Climate Data: http://www.worldclim.org

Data on river/stream surface and $k$ values from: http://www.nature.com/nature/ journal/v503/n7476/abs/nature12760.html\#supplementary-information

\section{References}

30. Richardson, D. C., Newbold, J. D., Aufdenkampe, A. K., Taylor, P. G. \& Kaplan, L. A. Measuring heterotrophic respiration rates of suspended particulate organic carbon from stream ecosystems. Limnol. Oceanogr. 11, 247-261 (2013).
31. Weiss, R. F. Determinations of carbon dioxide and methane by dual catalyst flame ionization chromatography and nitrous oxide by electron capture chromatography. J. Chromatogr. Sci. 19, 611-616 (1981).

32. Yamamoto, S., Alcauskas, J. B. \& Crozier, T. E. Solubility of methane in distilled water and seawater. J. Chem. Eng. Data 21, 78-80 (1976).

33. Weiss, R. F. \& Price, B. A. Nitrous oxide solubility in water and seawater. Mar. Chem. 8, 347-359 (1980).

34. Koné, Y. J. M., Abril, G., Delille, B. \& Borges, A. V. Seasonal variability of methane in the rivers and lagoons of Ivory Coast (West Africa). Biogeochemistry 100, 21-37 (2010).

35. Bouillon, S., Korntheuer, M., Baeyens, W. \& Dehairs, F. A new automated setup for stable isotope analysis of dissolved organic carbon. Limnol. Oceanogr. 4, 216-226 (2006).

36. Standing Committee of Analysts Methods for the Examination of Waters and Associated Materials (HMSO, 1981).

37. Standard Methods for the Examination of Water and Wastewater (APHA, 1998).

38. Miranda, K. M. et al. A rapid, simple spectrophotometric method for simultaneous detection of nitrate and nitrite. Nitric Oxide 5, 62-71 (2001).

39. Liss, P. S. \& Slater, P. G. Flux of gases across the air-sea interface. Nature 247, 181-184 (1974).

40. Weiss, R. F. Carbon dioxide in water and seawater: The solubility of a non-ideal gas. Mar. Chem. 2, 203-215 (1974).

41. Raymond, P. A. et al. Scaling the gas transfer velocity and hydraulic geometry in streams and small rivers. Limnol. Oceanogr. 2, 41-53 (2012).

42. Wanninkhof, R. Relationship between wind speed and gas exchange over the ocean. J. Geophys. Res. 97, 7373-7382 (1992).

43. Frankignoulle, M. Field measurements of air-sea $\mathrm{CO}_{2}$ exchange. Limnol. Oceanogr. 33, 313-322 (1988).

44. Raymond, P. A. \& Cole, J. J. Gas exchange in rivers and estuaries: Choosing a gas transfer velocity. Estuaries 24, 312-317 (2001).

45. Guérin, F. et al. Gas transfer velocities of $\mathrm{CO}_{2}$ and $\mathrm{CH}_{4}$ in a tropical reservoir and its river downstream. J. Mar. Syst. 66, 161-172 (2007).

46. Huotari, J., Haapanala, S., Pumpanen, J., Vesala, T. \& Ojala, A. Efficient gas exchange between a boreal river and the atmosphere. Geophys. Res. Lett. 40, 5683-5686 (2013).

47. Gålfalk, M., Bastviken, D., Fredriksson, S. \& Arneborg, L. Determination of the piston velocity for water-air interfaces using flux chambers, acoustic Doppler velocimetry, and IR imaging of the water surface. J. Geophys. Res. 118, 770-782 (2013).

48. Crawford, J. T. et al. Ebullitive methane emissions from oxygenated wetland streams. Glob. Change Biol. 20, 3408-3422 (2014).

49. DelSontro, T. et al. Spatial Heterogeneity of methane ebullition in a large tropical reservoir. Environ. Sci. Technol. 45, 9866-9873 (2011).

50. Deshmukh, C. et al. Physical controls on $\mathrm{CH}_{4}$ emissions from a newly flooded subtropical freshwater hydroelectric reservoir: Nam Theun 2. Biogeosciences 11, 4251-4269 (2014).

51. Maeck, A., Hofmann, H. \& Lorke, A. Pumping methane out of aquatic sediments - ebullition forcing mechanisms in an impounded river. Biogeosciences 11, 2925-2938 (2014).

52. Bouillon, S. et al. Organic matter sources, fluxes and greenhouse gas exchange in the Oubangui River (Congo River basin). Biogeosciences 9 , 2045-2062 (2012).

53. Bouillon, S. et al. Contrasting biogeochemical characteristics of right-bank tributaries and a comparison with the mainstem Oubangui River, Central African Republic (Congo River basin). Sci. Rep. 4, 5402 (2014).

54. Bouillon, S. et al. Distribution, origin and cycling of carbon in the Tana River (Kenya): A dry season basin-scale survey from headwaters to the delta. Biogeosciences 6, 2475-2493 (2009).

55. HYDRO1K Elevation Derivative Database (US Geological Survey, 2000).

56. Mayaux, P., Bartholomé, E., Fritz, S. \& Belward, A. A new land-cover map of Africa for the year 2000. J. Biogeogr. 31, 861-877 (2004).

57. Baccini, A., Laporte, N., Goetz, S. J., Sun, M. \& Dong, H. A first Map of tropical Africa's above-ground biomass derived from satellite imagery. Environ. Res. Lett. 3, 045011 (2008).

58. Lehner, B. \& Döll, P. Development and validation of a global database of lakes, reservoirs and wetlands. J. Hydrol. 296, 1-22 (2004).

59. Olivry, J. C. Fleuves et Rivières du Cameroun (MESCES - ORSTOM, 1986).

60. Hijmans, R. J., Cameron, S. E., Parra, J. L., Jones, P. G. \& Jarvis, A. Very high resolution interpolated climate surfaces for global land areas. Int. J. Clim. 25, 1965-1978 (2005). 


\section{Globally significant greenhouse-gas emissions from African inland waters}

Alberto V. Borges, François Darchambeau, Cristian R. Teodoru, Trent R. Marwick, Fredrick Tamooh, Naomi Geeraert, Fredrick O. Omengo, Frédéric Guérin, Thibault Lambert, Cédric Morana, Eric Okuku and Steven Bouillon 
Figure S1. Sampling stations, catchment and river network of the studied Sub-Saharan rivers.

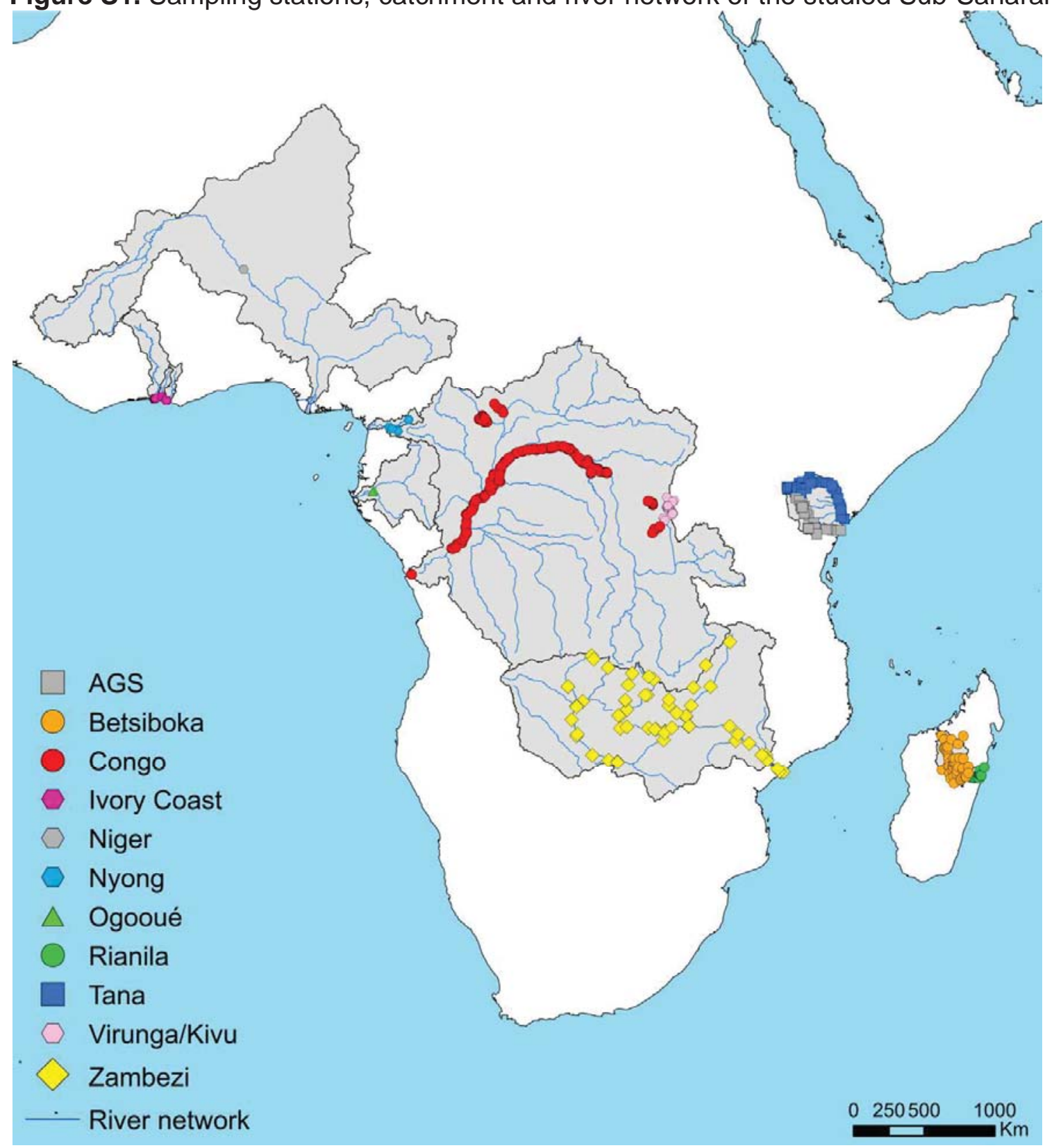


Figure S2. Box and whisker plots of $\mathrm{pCO}_{2}, \mathrm{CH}_{4}, \mathrm{~N}_{2} \mathrm{O}$ and $\% \mathrm{O}_{2}$ in the studied Sub-Saharan rivers. Data were categorized into small (<100 m width) and larger ( $>100 \mathrm{~m}$ width) rivers/streams. The horizontal line corresponds to the median, the cross to the average, error bars correspond to the 5 and 95 percentile, symbols to outliers.
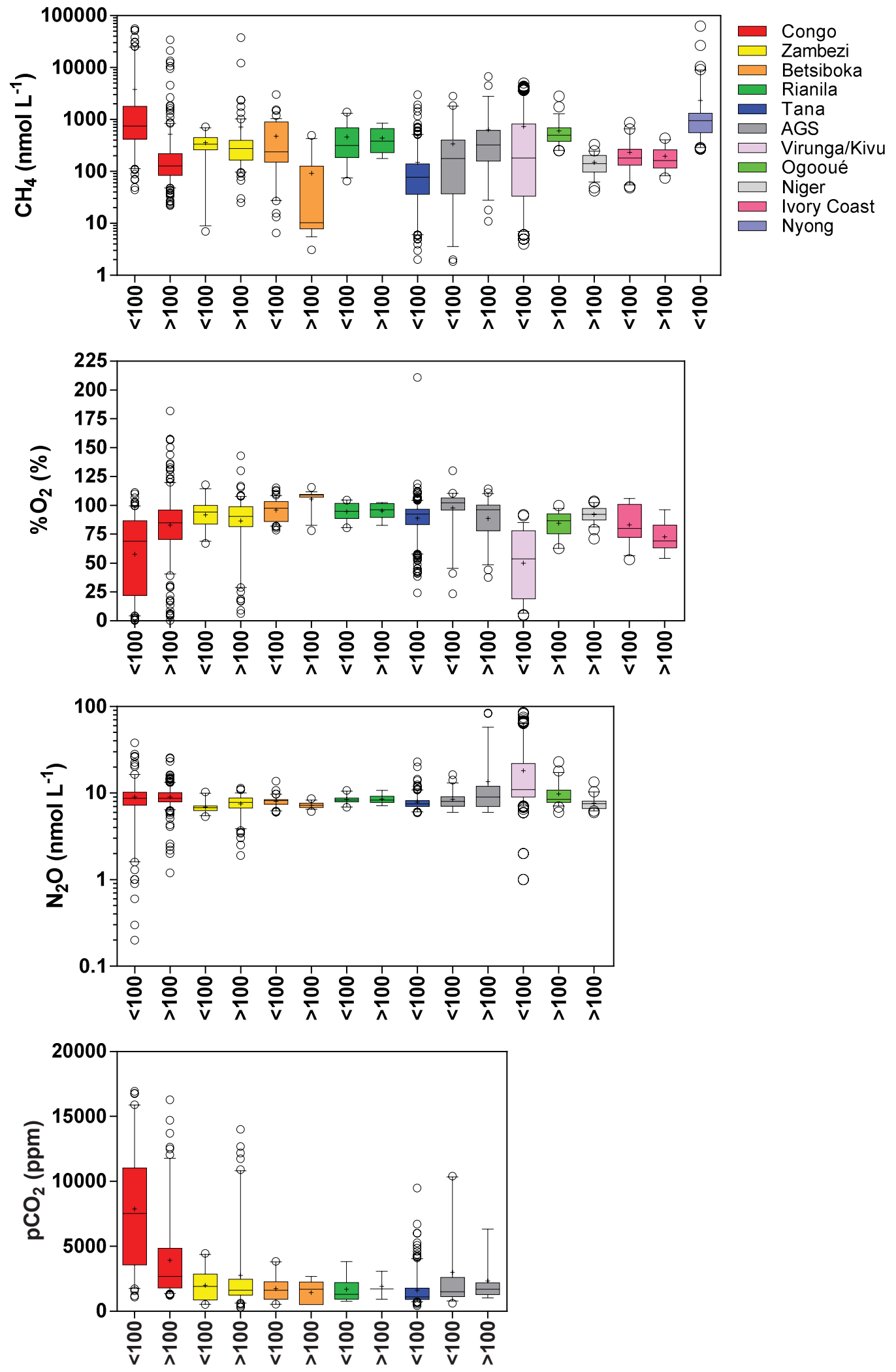
Figure S3. Comparison of the basin-wide averages of $\mathrm{pCO}_{2}$ and $\mathrm{FCO}_{2}$ reported in the present study and by $^{3}$ for the Congo, Zambezi, Tana, Rianila and Betsiboka Rivers. The strongest deviations in $\mathrm{pCO}_{2}$ between data from this study and the modelled data from ${ }^{3}$ were observed for the rivers (Zambezi and Congo) with extensive wetland coverage (5 and 10\% of the total catchment, respectively).

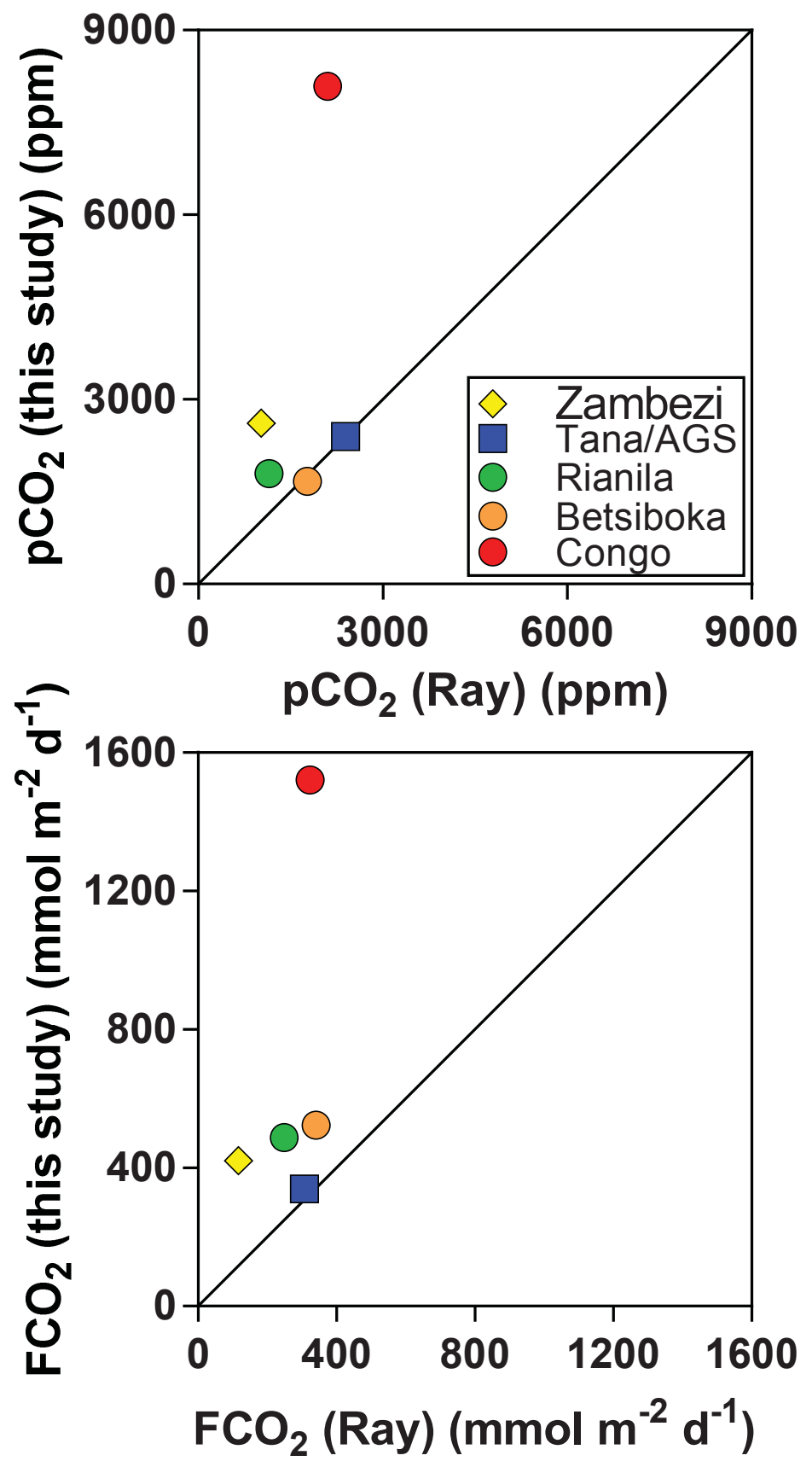


Figure S4. Comparison of the $\mathrm{CH}_{4}$ flux calculated from the $k_{600}$ derived from the corresponding chamber $\mathrm{FCO}_{2}$ (that should correspond exclusively to the diffusive $\mathrm{CH}_{4}$ flux) and the $\mathrm{CH}_{4}$ flux measured with the floating chamber (that integrates the ebullition $\mathrm{CH}_{4}$ flux and the diffusive $\mathrm{CH}_{4}$ flux). The difference between both approaches corresponds to the ebullition $\mathrm{CH}_{4}$ flux. The highest ebullition flux (2575 times higher than the diffusive $\mathrm{CH}_{4}$ flux) was measured in a Vossia cuspidata patch in Congo River.

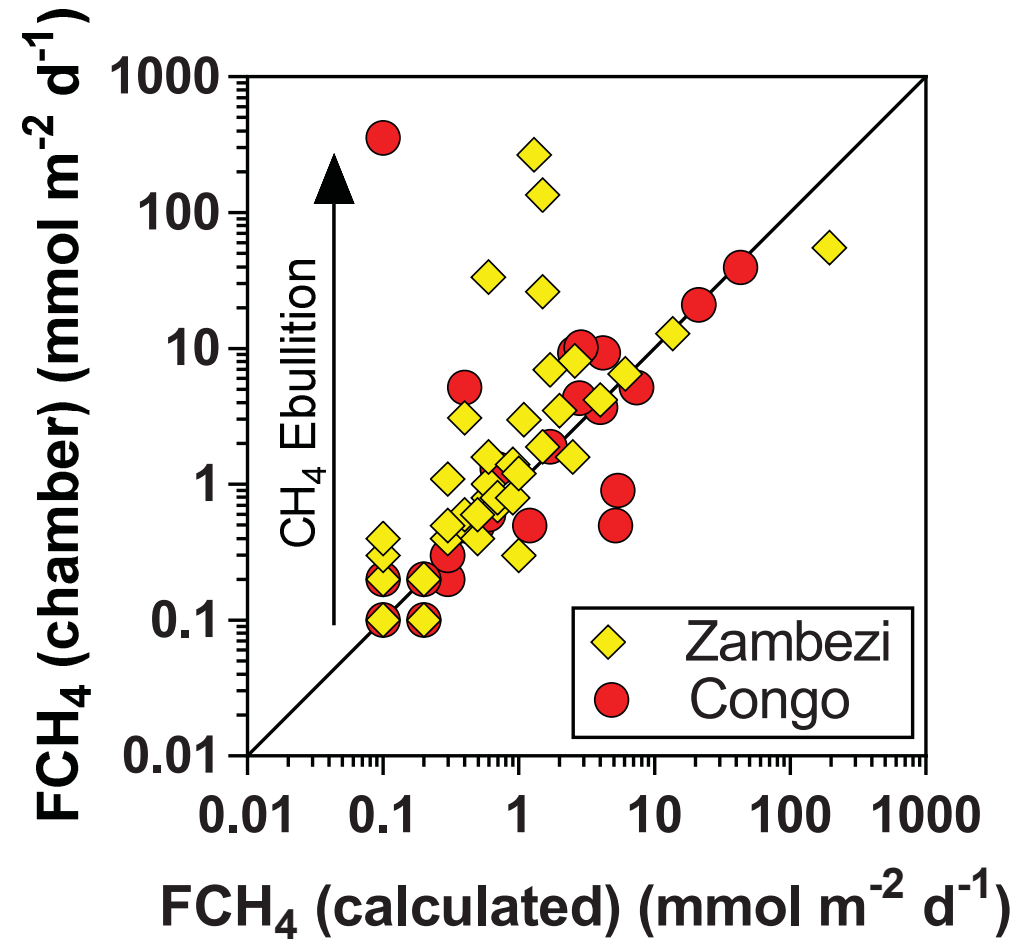


Figure S5. $\mathrm{N}_{2} \mathrm{O}$ as a function of $\% \mathrm{O}_{2}, \mathrm{NO}_{3}{ }^{-}, \mathrm{NH}_{4}{ }^{+}$and DIN in the studied African rivers.
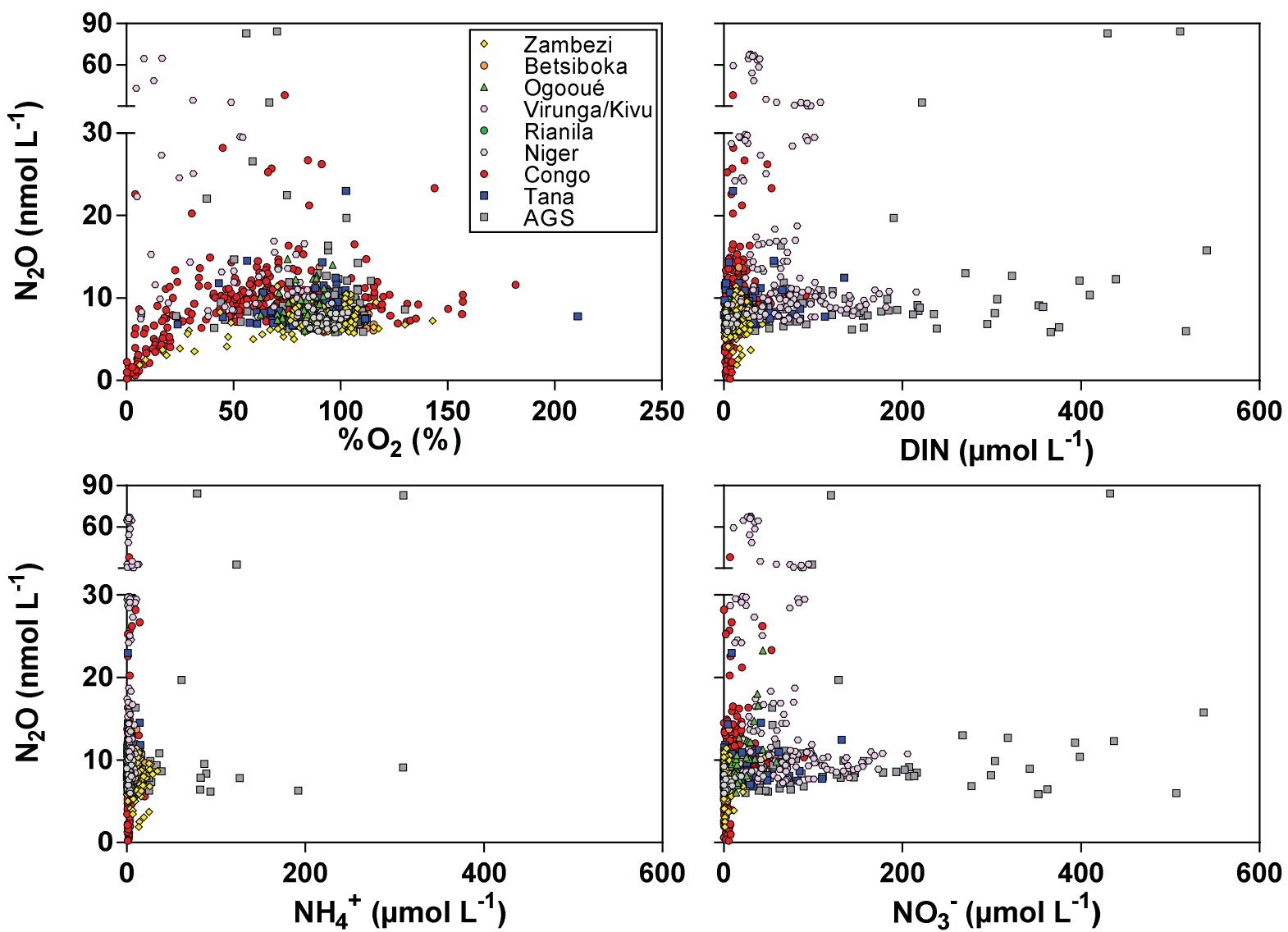
Figure S6. $\mathrm{N}_{2} \mathrm{O}$ as a function of $\mathrm{NO}_{3}{ }^{-}$from seasonal monitoring on the mainstem (fixed station) in the Oubangui (Congo River), Niger and Ogooué.

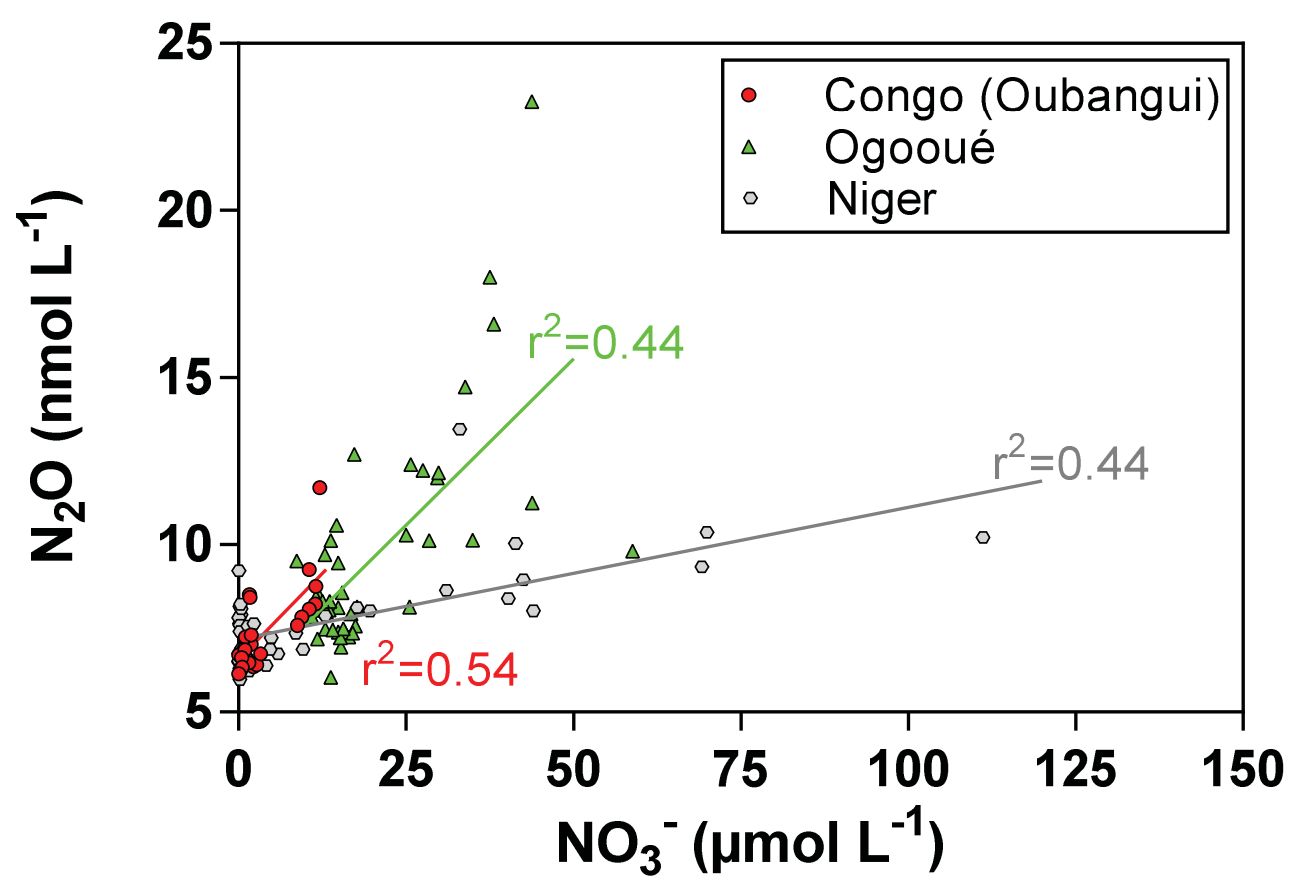


Figure S7. $\mathrm{CH}_{4}, \mathrm{pCO}_{2}, \mathrm{~N}_{2} \mathrm{O}$ and $\% \mathrm{O}_{2}$ as a function of water temperature and altitude in the studied African rivers.
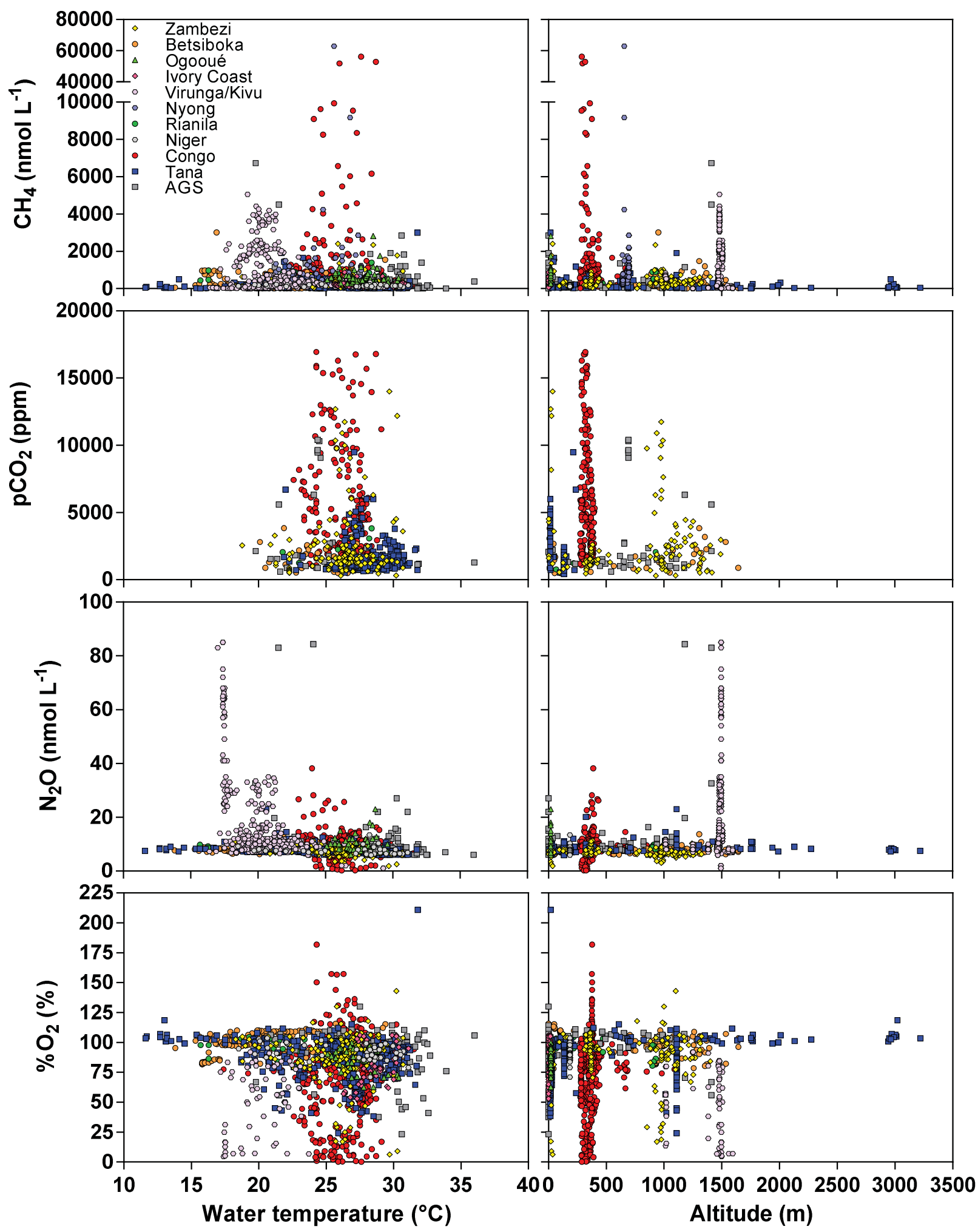
Figure S8. $\mathrm{pH}$ and $\% \mathrm{O}_{2}$ as a function of $\mathrm{DOC}$ in the studied African rivers.

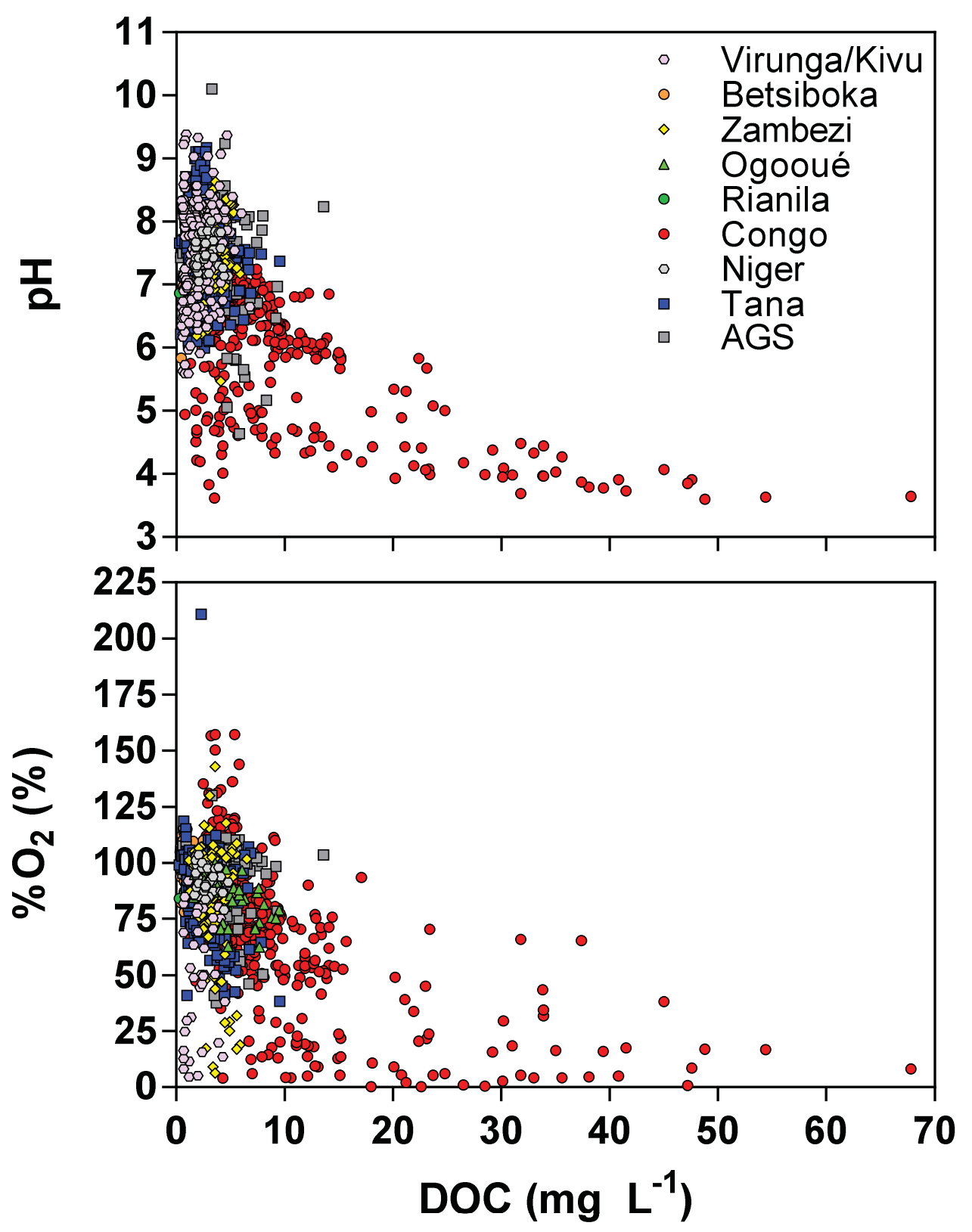


Fig. S9. Longitudinal variations in the Congo mainstem and tributaries along a transect in December 2013 (high water) from Kisangani to Kinshasa of $\mathrm{pCO}_{2}(\mathrm{ppm}), \mathrm{CH}_{4}\left(\mathrm{nmol} \mathrm{L}^{-1}\right)$ and $\% \mathrm{O}_{2}(\%)$, and aboveground woody biomass $\left(\mathrm{Mg} \mathrm{km}^{-2}\right)^{57}, \%$ of dense forest cover $(\%)^{56}$, and wetland surface (cumulated surface and fraction of catchment) ${ }^{58}$. The strong increase in cumulated wetland surface between 200 and $700 \mathrm{~km}$ upstream of Kinshasa corresponds to the core of the "Cuvette Centrale". About $200 \mathrm{~km}$ upstream of Kinshasa, the catchment becomes dominated by shrubby savannah. Aboveground biomass and dense forest cover increase gradually along the transect and decrease $200 \mathrm{~km}$ above Kinshasa with savannahs becoming more prevalent. The $\mathrm{pCO}_{2}$ and $\mathrm{CH}_{4}$ concentration increase downstream towards the "Cuvette Centrale" and collapse in the savannah area upstream of Kinshasa. These patterns are mirrored by $\% \mathrm{O}_{2}(\%)$.
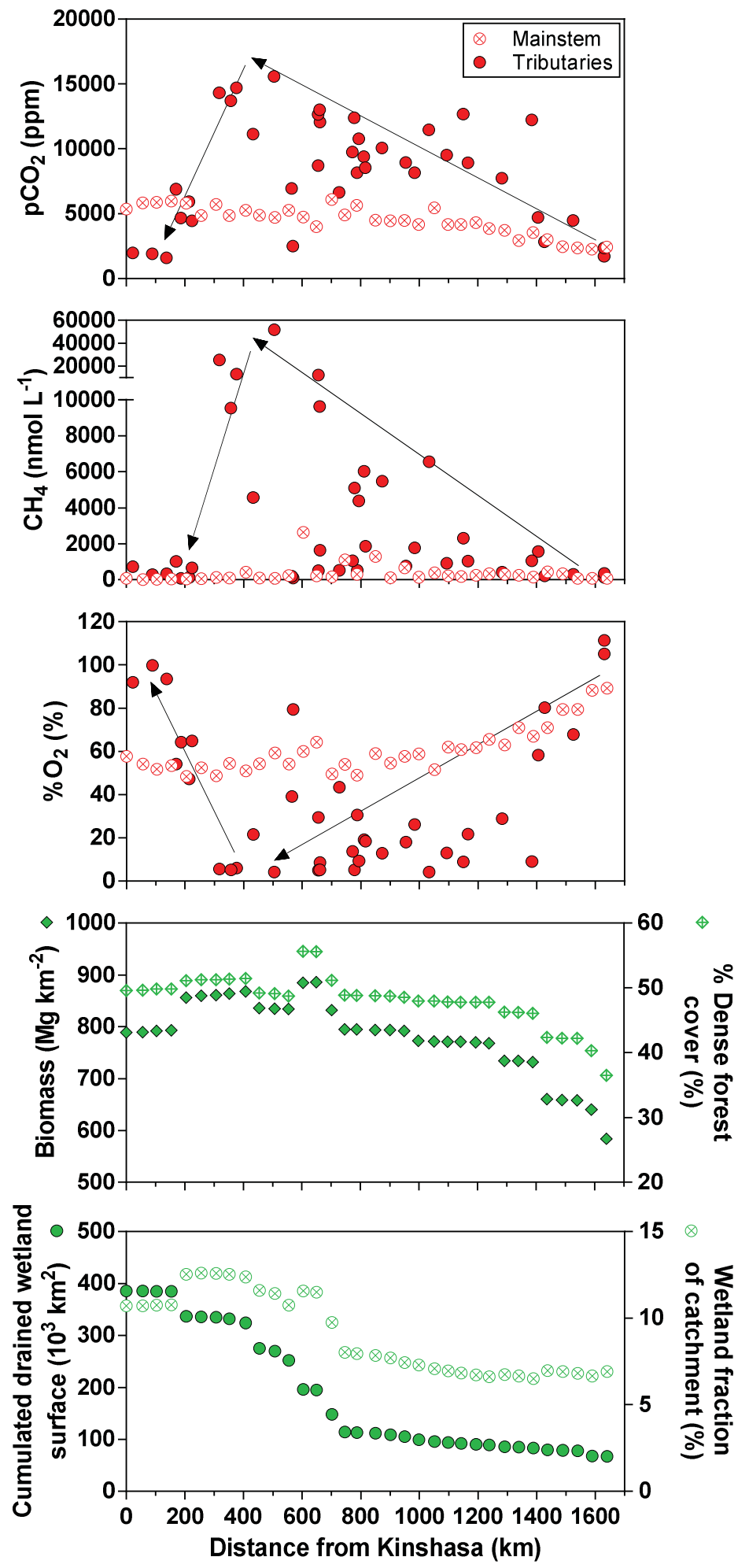
Fig. S10. $\mathrm{pCO}_{2}(\mathrm{ppm}), \mathrm{CH}_{4}\left(\mathrm{nmol} \mathrm{L}^{-1}\right), \mathrm{N}_{2} \mathrm{O}\left(\mathrm{nmol} \mathrm{L}{ }^{-1}\right)$ and $\% \mathrm{O}_{2}(\%)$ in 46 rivers of the Congo basin as function of dense forest cover $^{56}$ and aboveground woody biomass $\left(\mathrm{Mg} \mathrm{km}^{-2}\right)^{57}$ on the catchment $^{55}$. Data were bin-averaged by intervals of $25 \%$ of dense forest cover and by intervals of $400 \mathrm{Mg} \mathrm{km}^{-2}$ of biomass. Two extreme $\mathrm{CH}_{4}$ values (>25000 $\mathrm{nmol} \mathrm{L^{-1 }}$ ) were removed from the analysis. Error bars correspond to the standard deviation on the mean.
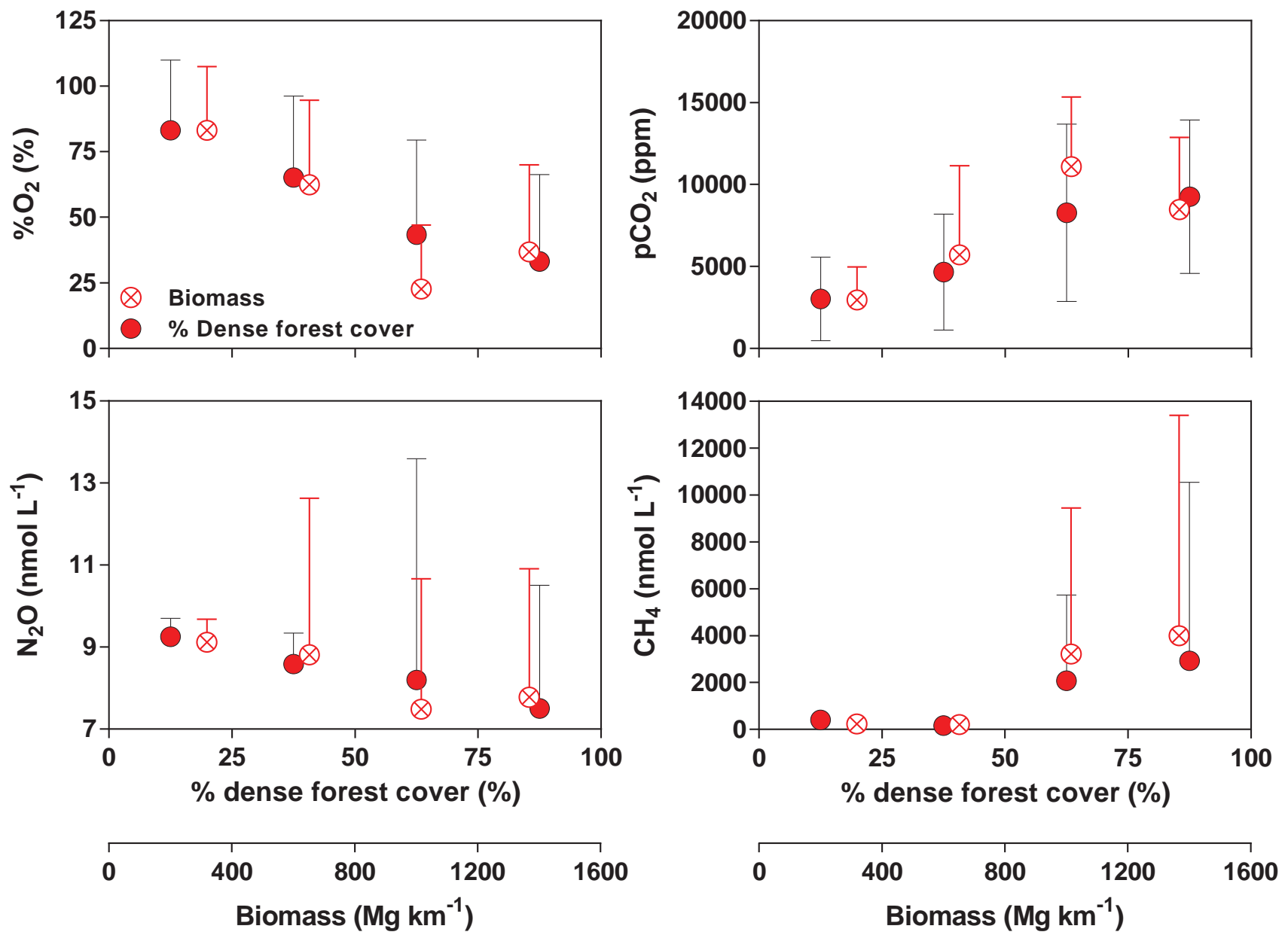
Figure S11. $\mathrm{pCO}_{2}(\mathrm{ppm}), \mathrm{CH}_{4}\left(\mathrm{nmol} \mathrm{L}{ }^{-1}\right)$ and $\% \mathrm{O}_{2}(\%)$ as function of dense forest cover (\%) ${ }^{56}$, of aboveground living biomass $\left(\mathrm{Mg} \mathrm{km}^{-2}\right)^{57}$, average catchment slope ${ }^{55}$, and precipitation ${ }^{61}$. Only the data-sets that capture spatial variations were included in the analysis (excluding fixed time-series in the mainstem of rivers).
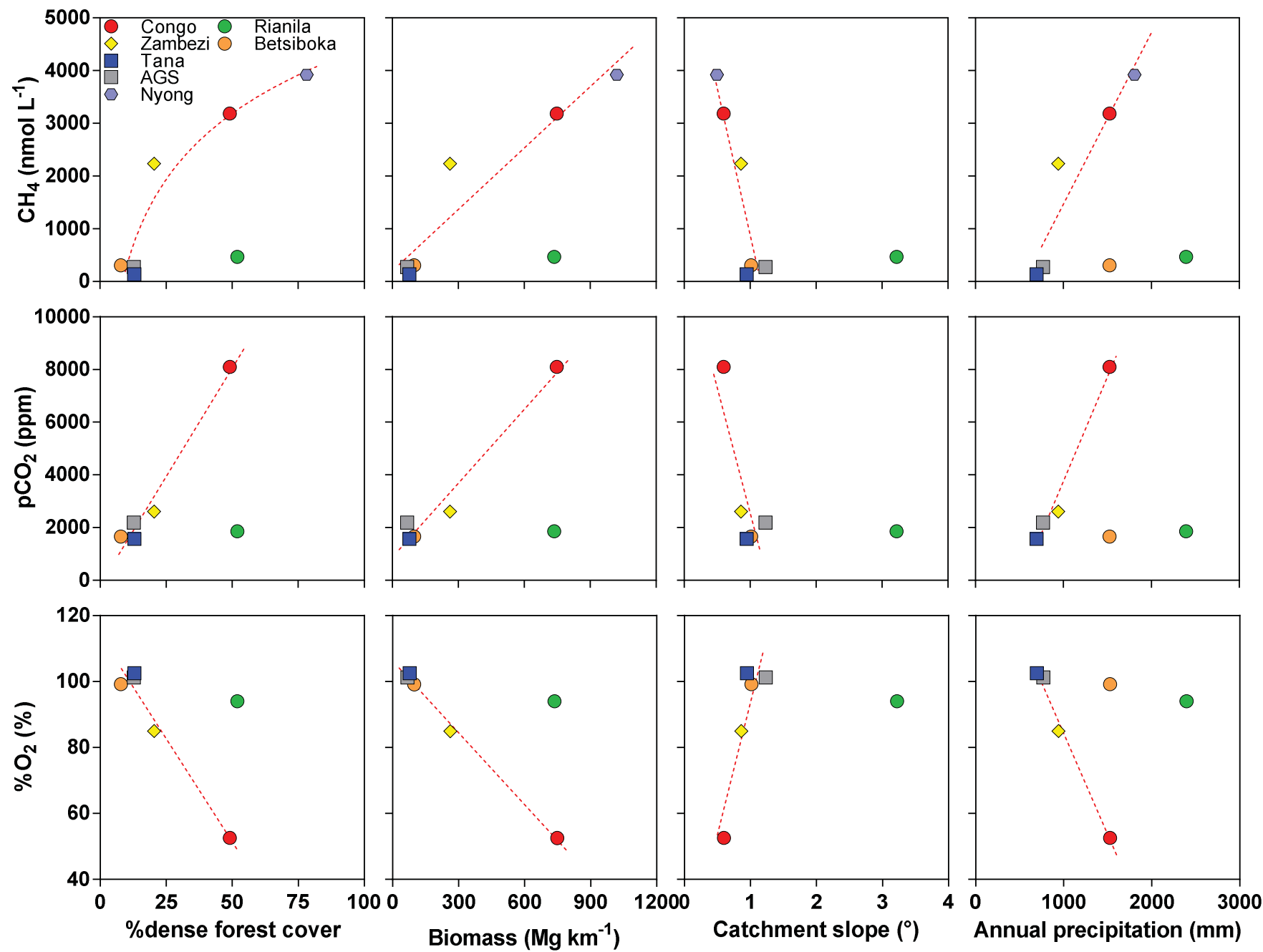
Figure S12. Frequency distribution of the pelagic R measurements gathered in the studied SubSaharan rivers.

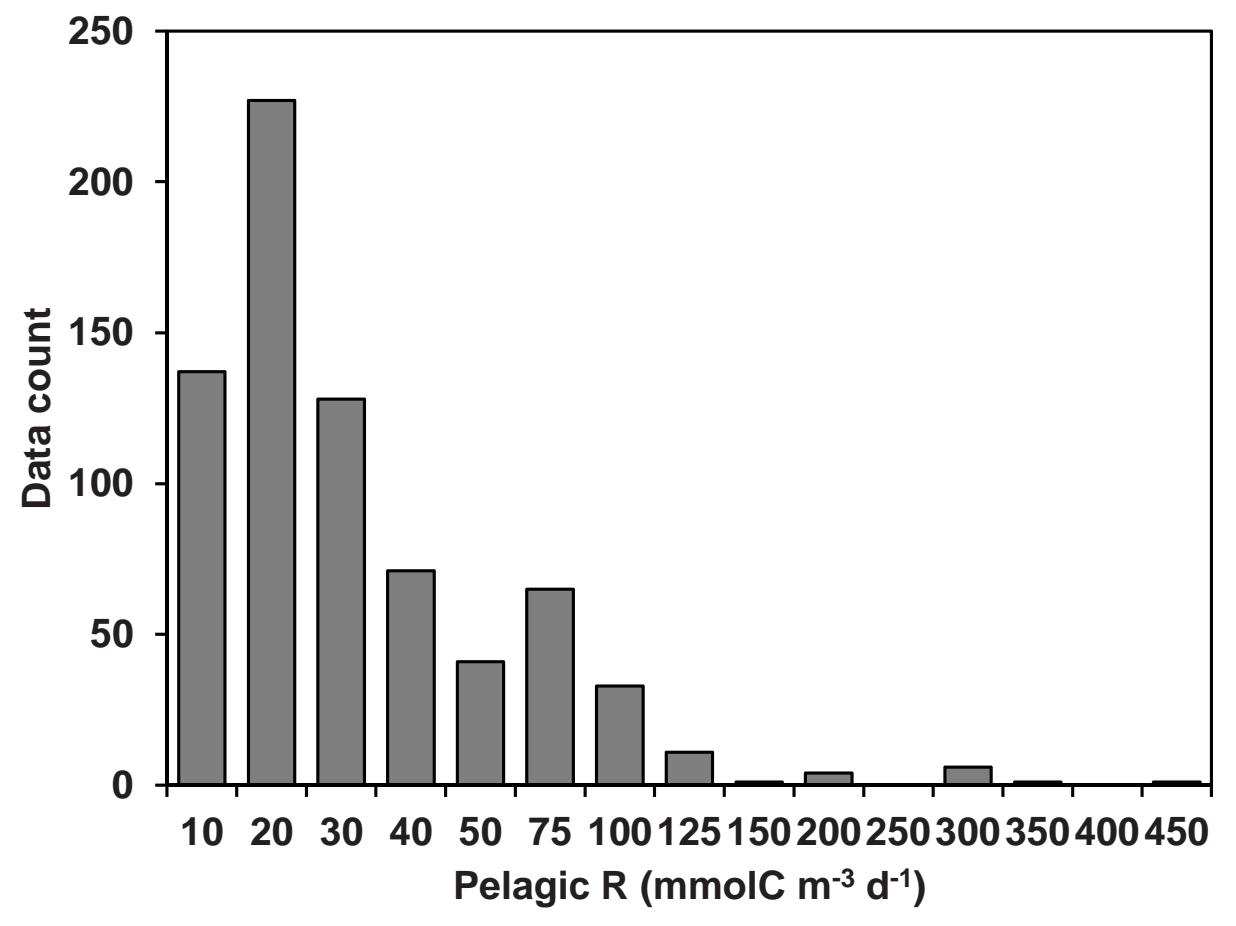


Table S1. Summary of sample collection for GHGs and pelagic respiration (R) in African rivers and streams. Unpubl. = unpublished

\begin{tabular}{|c|c|c|c|c|c|c|c|c|c|}
\hline & Approach & Dates & Longitude $\left({ }^{\circ} \mathrm{E}\right)$ & Latitude $\left({ }^{\circ} \mathrm{N}\right)$ & $n \mathrm{pCO}_{2}$ & $n \mathrm{CH}_{4}$ & $n \mathrm{~N}_{2} \mathrm{O}$ & $n \mathrm{R}$ & Reference \\
\hline Congo & Survey & 03/12/2013 - 19/12/2013 & $15.350 ; 25.187$ & $-4.307 ; 2.206$ & 75 & 75 & 75 & 67 & Unpubl. \\
\hline Congo & Survey & $10 / 06 / 2014$ - 30/06/2014 & $15.357 ; 25.187$ & $-4.306 ; 2.217$ & 89 & 89 & 89 & 69 & Unpubl. \\
\hline Congo & Survey & $13 / 03 / 2014-21 / 03 / 2014$ & $24.170 ; 24.604$ & $0.493 ; 0.784$ & 20 & 20 & 20 & 2 & Unpubl. \\
\hline Congo & Survey & $17 / 09 / 2013-26 / 09 / 2013$ & $24.169 ; 24.599$ & $0.494 ; 0.775$ & 6 & 7 & 7 & 7 & Unpubl. \\
\hline Congo & Survey & 20/11/2012 - 08/12/2012 & $24.170 ; 25.196$ & $0.490 ; 0.795$ & 32 & 32 & 32 & 21 & Unpubl. \\
\hline Congo & Monitoring & $10 / 12 / 2012$ - 29/05/2014 & 25.200 & 0.499 & & 37 & 37 & & Unpubl. \\
\hline Congo & Monitoring & $11 / 12 / 2012-29 / 05 / 2014$ & 25.186 & 0.542 & & 36 & 36 & & Unpubl. \\
\hline Congo & Survey & 20/12/2010 - 31/12/2010 & $27.803 ; 28.574$ & $-3.310 ;-1.283$ & & 15 & 15 & & Unpubl. \\
\hline Congo & Survey & $21 / 03 / 2010-23 / 03 / 2010$ & $17.025 ; 18.469$ & $3.945 ; 4.919$ & & 7 & 7 & & {$[52 ; 53]$} \\
\hline Congo & Survey & $20 / 03 / 2011-23 / 03 / 2011$ & $17.110 ; 17.529$ & $3.754 ; 4.105$ & & 16 & 16 & & {$[52 ; 53]$} \\
\hline Congo & Survey & 20/11/2012 - 24/11/2012 & $17.157 ; 17.535$ & $3.755 ; 4.081$ & & 14 & 14 & & {$[52 ; 53]$} \\
\hline Congo & Monitoring & 20/03/2010 - 31/03/2012 & 18.567 & 4.350 & & 54 & 54 & & {$[52 ; 53]$} \\
\hline Congo & Survey & 01/05/2010 - 06/06/2010 & $22.458 ; 25.181$ & $0.475 ; 2.172$ & & 52 & 52 & 41 & Unpubl. \\
\hline Congo & Monitoring & $22 / 07 / 2011-23 / 11 / 2012$ & 15.276 & -4.296 & & 29 & 28 & & Unpubl. \\
\hline Congo & Survey & 02/05/2010 - 22/07/2011 & $15.276 ; 25.181$ & $-4.296 ; 2.172$ & & 52 & 52 & 40 & Unpubl. \\
\hline Congo & Survey & 22/06/2012 - 24/06/2012 & $12.705 ; 12.733$ & $-5.964 ;-5.956$ & & 2 & 2 & & Unpubl. \\
\hline Congo & Survey & $22 / 06 / 2012-24 / 06 / 2012$ & $12.705 ; 12.733$ & $-5.964 ;-5.964$ & & 2 & 2 & & Unpubl. \\
\hline Virunga Rivers (12) & Monitoring & $18 / 12 / 2010-20 / 02 / 2013$ & $29.004 ; 29.478$ & $-1.727 ;-1.028$ & & 291 & 290 & & Unpubl. \\
\hline Kivu Rivers & Survey & $17 / 03 / 2007-22 / 03 / 2007$ & $28.788 ; 29.411$ & $-2.470 ;-1.991$ & & 12 & & & Unpubl. \\
\hline Kivu Rivers & Survey & 28/08/2007 - 10/09/2007 & $28.788 ; 29.411$ & $-2.505 ;-1.992$ & & 13 & & & Unpubl. \\
\hline Kivu Rivers & Survey & $21 / 06 / 2008-26 / 06 / 2008$ & $28.788 ; 29.411$ & $-2.505 ;-1.992$ & & 12 & & & Unpubl. \\
\hline Kivu Rivers & Survey & $22 / 04 / 2009-05 / 05 / 2009$ & $28.788 ; 29.411$ & $-2.505 ;-1.991$ & & 12 & 12 & & Unpubl. \\
\hline Kivu Rivers & Survey & 20/10/2010 - 24/10/2010 & $28.789 ; 29.072$ & $-2.505 ;-1.574$ & & 8 & 8 & & Unpubl. \\
\hline Kivu Rivers & Survey & $25 / 06 / 2011$ - 25/06/2011 & $28.788 ; 28.837$ & $-2.470 ;-2.362$ & & 5 & 5 & 5 & Unpubl. \\
\hline Kivu Rivers & Survey & 27/01/2012 - 27/01/2012 & $28.788 ; 28.837$ & $-2.470 ;-2.362$ & & 5 & 5 & 5 & Unpubl. \\
\hline Ivory Coast (Comoé) & Monitoring & $22 / 06 / 2006-21 / 03 / 2007$ & -3.669 & 5.241 & & 31 & & & [34] \\
\hline Ivory Coast (Bia) & Monitoring & 08/06/2006 - 08/03/2007 & -3.210 & 5.370 & & 30 & & & [34] \\
\hline Ivory Coast (Tanoé) & Monitoring & $13 / 06 / 2006-13 / 03 / 2007$ & -2.920 & 5.123 & & 25 & & & {$[34]$} \\
\hline Ogooué & Monitoring & $19 / 04 / 2012-18 / 04 / 2014$ & 10.225 & -0.706 & & 55 & 53 & & Unpubl. \\
\hline Niger & Monitoring & 03/04/2011 - 17/03/2013 & 2.006 & 13.567 & & 49 & 49 & & Unpubl. \\
\hline Zambezi & Survey & 04/02/2012 - 27/04/2012 & $22.688 ; 36.193$ & $-18.549 ;-11.122$ & 50 & 52 & 52 & 44 & {$[25]$} \\
\hline Zambezi & Survey & $12 / 01 / 2013-15 / 03 / 2013$ & $22.689 ; 36.445$ & $-18.579 ;-8.596$ & 55 & 45 & 45 & 37 & [25] \\
\hline Zambezi & Survey & $19 / 10 / 2013-24 / 11 / 2013$ & $22.685 ; 30.414$ & $-17.887 ;-11.350$ & 32 & 30 & 30 & 16 & {$[25]$} \\
\hline Zambezi (2 rivers) & Monitoring & $19 / 02 / 2012-24 / 11 / 2013$ & $28.858 ; 28.875$ & $-16.035 ;-15.946$ & 16 & 55 & 55 & 57 & Unpubl. \\
\hline Madagascar & Survey & 04/07/2010 - 03/09/2010 & $46.547 ; 49.268$ & $-19.295 ;-16.233$ & & 121 & 121 & 56 & Unpubl. \\
\hline Madagascar & Survey & $21 / 01 / 2012-01 / 03 / 2012$ & $46.547 ; 49.026$ & $-19.295 ;-16.233$ & 36 & 49 & 49 & 43 & Unpubl. \\
\hline Tana & Survey & 03/09/2012 - 09/09/2012 & $39.340 ; 39.472$ & $-4.422 ;-4.158$ & 9 & 10 & 10 & 9 & Unpubl. \\
\hline Tana & Survey & $12 / 02 / 2008-24 / 02 / 2008$ & $36.708 ; 40.352$ & $-2.410 ;-0.062$ & & 24 & & & {$[54]$} \\
\hline Tana & Survey & 03/06/2010 - 22/07/2010 & $36.674 ; 40.352$ & $-2.410 ; 0.269$ & & 98 & 98 & & Unpubl. \\
\hline Tana (1 river) & Monitoring & $14 / 12 / 2010-16 / 07 / 2013$ & 37.269 & -0.787 & & 51 & 51 & & Unpubl. \\
\hline Tana (5 sites) & Monitoring & $25 / 06 / 2010-02 / 01 / 2012$ & $38.311 ; 40.115$ & $-1.851 ;-0.055$ & & 78 & 76 & & Unpubl. \\
\hline Tana (2 sites) & Monitoring & $11 / 09 / 2011-16 / 12 / 2013$ & $39.636 ; 40.115$ & $-1.851 ;-0.464$ & & 106 & 102 & & Unpubl. \\
\hline Tana (2 sites) & Monitoring & $13 / 10 / 2012$ - 20/05/2014 & $39.636 ; 40.117$ & $-2.269 ;-0.464$ & 247 & & & 245 & Unpubl. \\
\hline Athi-Galana-Sabaki & Survey & $01 / 11 / 2011$ - 21/11/2011 & $37.253 ; 40.108$ & $-3.391 ;-1.078$ & 28 & 29 & 30 & 26 & {$[22]$} \\
\hline Athi-Galana-Sabaki & Survey & $17 / 04 / 2012-01 / 05 / 2012$ & $37.253 ; 40.108$ & $-3.144 ;-1.078$ & 16 & 22 & 22 & 22 & {$[22]$} \\
\hline Athi-Galana-Sabaki & Monitoring & 08/09/2011 - 14/12/2013 & 40.108 & -3.144 & & 57 & 53 & & Unpubl. \\
\hline Nyong (6 sites) & Monitoring & $26 / 02 / 2009-15 / 05 / 2010$ & $11.283 ; 12.533$ & $3.167 ; 3.900$ & & 100 & & & Unpubl. \\
\hline
\end{tabular}


Table S2. Characteristics of the 12 studied African rivers. AGS = Athi-Galana-Sabaki River.

\begin{tabular}{|c|c|c|c|c|c|c|c|c|c|c|c|c|}
\hline & AGS & Betsiboka & Bia & Comoé & Congo & Niger & Nyong & Ogooué & Rianila & Tana & Tanoé & Zambezi \\
\hline Catchment area $\left(\mathrm{km}^{2}\right)^{55}$ & 40300 & 68311 & 11917 & 78474 & 3705222 & 2098640 & 27415 & 215216 & 7844 & 100608 & 15608 & 1378102 \\
\hline Slope $\left({ }^{\circ}\right)^{56}$ & 1.23 & 1.02 & 0.36 & 0.48 & 0.60 & 0.44 & 0.50 & 0.49 & 3.22 & 0.95 & 0.58 & 0.86 \\
\hline Discharge $\left(\mathrm{km}^{3} \mathrm{yr}^{-1}\right)$ & 2.30 & 9.49 & 1.86 & 7.06 & 1292.98 & 200.00 & 12.30 & 148.22 & 12.87 & 4.92 & 4.16 & 130.37 \\
\hline Precipitation $(\mathrm{mm})^{59}$ & 769 & 1527 & 1545 & 1174 & 1527 & 646 & 1809 & 1794 & 2397 & 696 & 1529 & 940 \\
\hline River-stream surface $\left(\mathrm{km}^{2}\right)^{3}$ & 359 & 1105 & 105 & 690 & 26517 & 4118 & 222 & 4261 & 1125 & 895 & 137 & 7325 \\
\hline Wetland surface $\left(\mathrm{km}^{2}\right)^{58,59,60}$ & 1181 & 1354 & 0 & 150 & 358756 & 119734 & 5483 & 12612 & 128 & 402 & 126 & 69254 \\
\hline Aboveground biomass $\left(\mathrm{Mg} \mathrm{km}^{-2}\right)^{57}$ & 67 & 98 & 479 & 279 & 7488 & 59 & 1022 & 984 & 736 & 77 & 489 & 262 \\
\hline \multicolumn{13}{|l|}{ Land cover $^{56}$} \\
\hline Dense Forest (\%) & 12.8 & 7.9 & 18.6 & 2.7 & 49.1 & 0.4 & 78.2 & 89.8 & 52.0 & 12.9 & 20.7 & 20.4 \\
\hline Mosaic Forest (\%) & 0.1 & 0.9 & 77.4 & 32.3 & 17.8 & 2.2 & 19.5 & 4.4 & 43.2 & 0.1 & 75.6 & 0.0 \\
\hline Woodland and shrubland (\%) & 10.2 & 15.5 & 0.8 & 58.7 & 26.6 & 21.1 & 1.6 & 2.2 & 1.0 & 8.1 & 3.0 & 54.6 \\
\hline Grassland (\%) & 59.5 & 75.3 & 0.0 & 0.0 & 2.9 & 23.4 & 0.2 & 3.2 & 0.4 & 71.2 & 0.0 & 8.7 \\
\hline Cropland / Bare soil (\%) & 16.5 & 0.0 & 0.0 & 6.3 & 1.7 & 52.2 & 0.0 & 0.1 & 0.0 & 7.4 & 0.0 & 13.4 \\
\hline
\end{tabular}


Table S3. Average values per river of $\mathrm{pCO}_{2}, \mathrm{CH}_{4}, \mathrm{~N}_{2} \mathrm{O}, \mathrm{FCO}_{2}, \mathrm{FCH}_{4}$ and $\mathrm{FN}_{2} \mathrm{O}$ computed according to ${ }^{2}$ (Auf) and ${ }^{3}$ (Ray), integrated at basin and Sub-Saharan continental scaled using the river/stream surface areas reported by ${ }^{3}$, and the export of TOC and DIC reported in literature for the Congo, the Zambezi and the Tana. AGS = Athi-Galana-Sabaki River

\begin{tabular}{|c|c|c|c|c|c|c|c|c|c|c|c|c|}
\hline & & Congo & Ivory Coast & Ogooué & Niger & Zambezi & Betsiboka & Rianila & Tana & AGS & Nyong & Total \\
\hline $\mathrm{pCO}_{2}$ & (ppm) & 8092 & & & & 2612 & 1665 & 1861 & 1571 & 2197 & & 6415 \\
\hline $\mathrm{CH}_{4}$ & $\left(\mathrm{nmol} \mathrm{L}{ }^{-1}\right)$ & 3184 & 223 & 606 & 149 & 2235 & 305 & 469 & 140 & 277 & 3922 & 2205 \\
\hline $\mathrm{N}_{2} \mathrm{O}$ & $\left(\mathrm{nmol} \mathrm{L}{ }^{-1}\right)$ & 10 & & 10 & 8 & 7 & 8 & 9 & 8 & 10 & & 9.2 \\
\hline $\mathrm{FCH}_{4}$ (Aufd) & $\left(\mu \mathrm{mol} \mathrm{m} \mathrm{m}^{-2} \mathrm{~d}^{-1}\right)$ & 14296 & 1003 & 2115 & 502 & 8348 & 1305 & 1923 & 568 & 1156 & 18019 & 9607 \\
\hline $\mathrm{FCH}_{4}$ (Ray) & $\left(\mu \mathrm{mol} \mathrm{m} \mathrm{m}^{-2} \mathrm{~d}^{-1}\right)$ & 18534 & 1667 & 4668 & 583 & 13597 & 3493 & 4537 & 604 & 1374 & 28579 & 13164 \\
\hline $\mathrm{FN}_{2} \mathrm{O}$ (Aufd) & $\left(\mu \mathrm{mol} \mathrm{m} \mathrm{m}^{-2} \mathrm{~d}^{-1}\right)$ & 15 & & 13 & 4 & 2 & 4 & 5 & 6 & 16 & & 11 \\
\hline $\mathrm{FN}_{2} \mathrm{O}$ (Ray) & $\left(\mu \mathrm{mol} \mathrm{m} \mathrm{m}^{-2} \mathrm{~d}^{-1}\right)$ & 19 & & 28 & 5 & 2 & 9 & 12 & 6 & 19 & & 15 \\
\hline $\mathrm{FCO}_{2}$ (Aufd) & $\left(\mathrm{mmol} \mathrm{m} \mathrm{m}^{-2} \mathrm{~d}^{-1}\right)$ & 1149 & & & & 283 & 194 & 214 & 186 & 274 & & 894 \\
\hline $\mathrm{FCO}_{2}$ (Ray) & $\left(\mathrm{mmol} \mathrm{m} \mathrm{m}^{-2} \mathrm{~d}^{-1}\right)$ & 1520 & & & & 421 & 523 & 509 & 198 & 306 & & 1205 \\
\hline $\mathrm{FCO}_{2}$ (Aufd) & 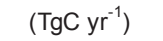 & 133.41 & & & & 9.08 & 0.94 & 1.06 & 1.02 & 0.04 & & 145.5 \\
\hline $\mathrm{FCO}_{2}$ (Ray) & $\left(\mathrm{TgC} \mathrm{yr}^{-1}\right)$ & 176.52 & & & & 13.52 & 2.53 & 2.51 & 1.09 & 0.05 & & 196.2 \\
\hline TOC export to sea & $\left(\mathrm{TgC} \mathrm{yr}^{-1}\right)$ & $10.00-14.40^{[62 ; 63]}$ & & & & $0.55^{[25]}$ & & & $0.04^{[65]}$ & & & \\
\hline DIC export to sea & $\left(\operatorname{TgC~yr} r^{-1}\right)$ & $3.20-3.46^{[15 ; 64]}$ & & & & $3.69^{[25]}$ & & & $0.06^{[65]}$ & & & \\
\hline TOC+DIC export to sea & $\left(\operatorname{TgC~} \mathrm{yr}^{-1}\right)$ & 15.53 & & & & 4.24 & & & 0.10 & & & \\
\hline
\end{tabular}


Table S4. $\mathrm{FCO}_{2}, \mathrm{FCH}_{4}$ and $\mathrm{FN}_{2} \mathrm{O}$ in $\mathrm{CO}_{2}$ equivalents in temperate rivers, the Ohio ${ }^{66}$ and four Belgian $^{67}$ (BE) rivers. The sampled African rivers (Fig. 1) were characterized by lower $\mathrm{FCO}_{2}: \mathrm{FCH}_{4}\left(\mathrm{CO}_{2}\right.$ equ) ratios and higher $\mathrm{FCO}_{2}: \mathrm{FN}_{2} \mathrm{O}\left(\mathrm{CO}_{2}\right.$ equ) than temperate rivers.

\begin{tabular}{lcccccc}
\hline & $\begin{array}{c}\mathrm{FCO}_{2} \\
\mathrm{mmol} \mathrm{m}^{-2} \mathrm{~d}^{-1}\end{array}$ & $\begin{array}{c}\mathrm{FCH}_{4} \\
\mu \mathrm{mol} \mathrm{m}^{-2} \mathrm{~d}^{-1}\end{array}$ & $\begin{array}{c}\mathrm{FN}_{2} \mathrm{O} \\
\mu \mathrm{mol} \mathrm{m}^{-2} \mathrm{~d}^{-1}\end{array}$ & $\begin{array}{c}\mathrm{FCO}_{2} \\
\mathrm{gC} \mathrm{m}^{-2} \mathrm{~d}^{-1}\end{array}$ & $\begin{array}{c}\mathrm{FCH}_{4} \\
\mathrm{gC} \mathrm{m}^{-2} \mathrm{~d}^{-1} \\
\left(\mathrm{CO}_{2} \text { equ }\right)\end{array}$ & $\begin{array}{c}\mathrm{FN}_{2} \mathrm{O} \\
\mathrm{gC} \mathrm{m}^{-2} \mathrm{~d}^{-1} \\
\left(\mathrm{CO}_{2} \text { equ }\right)\end{array}$ \\
\hline Ohio (USA) & 194 & 1188 & 23 & 2.33 & 0.12 & 0.08 \\
Ourthe (BE) & 67 & 110 & 7 & 0.80 & 0.01 & 0.03 \\
Meuse (BE) & 224 & 1060 & 22 & 2.69 & 0.11 & 0.08 \\
Geer (BE) & 1662 & 22460 & 550 & 19.94 & 2.25 & 1.97 \\
Blanc Gravier (BE) & 275 & 80 & 13 & 3.30 & 0.01 & 0.05 \\
\hline
\end{tabular}


Full data-set available from :

http://www.nature.com/ngeo/journal/vaop/ncurrent/extref/ngeo2486-s2.xlsx 